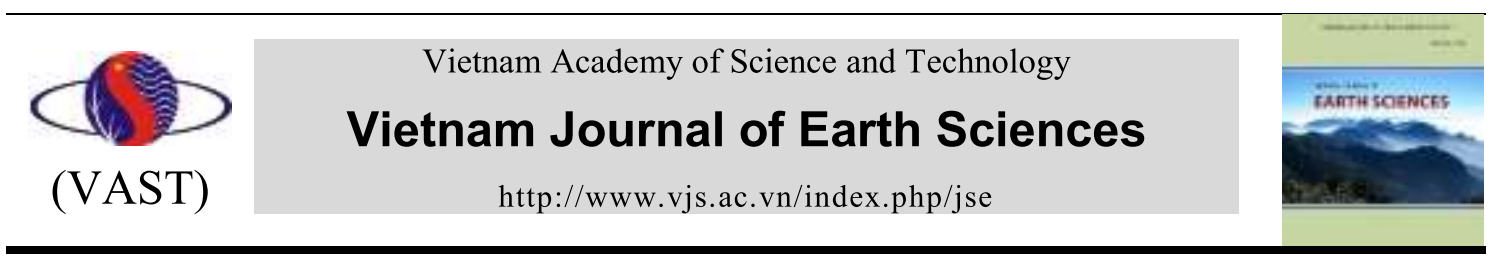

\title{
Geological values of lava caves in Krongno Volcano Geopark, Dak Nong, Vietnam
}

La The Phuc ${ }^{*}$, Hiroshi Tachihara ${ }^{2}$, Tsutomu Honda ${ }^{2}$, Luong Thi Tuat ${ }^{1}$, Bui Van Thom ${ }^{3}$, Nguyen Hoang3, Yuriko Chikano², Katsuji Yoshida ${ }^{2}$, Nguyen Thanh Tung4, Pham Ngoc Danh5, Nguyen Ba Hung1, Tran Minh Duc ${ }^{1}$, Pham Gia Minh Vuํㅗ , Nguyen Thi Mai Hoa ${ }^{1}$, Hoang Thi Bien ${ }^{6}$, Truong Quang Quy7, Nguyen Trung Minh ${ }^{1}$

${ }^{1}$ Vietnam National Museum of Nature (VNMN), Vietnam Academy of Science and Technology (VAST)

${ }^{2}$ NPO Vulcano-Speleological Society (VSS), Japan

${ }^{3}$ Institute of Geological Sciences (IGSVN), Vietnam Academy of Science and Technology (VAST)

${ }^{4}$ International Tour Guide, Dak Nong Province, Vietnam - VNMN's Collaborator

${ }^{5}$ Department of Science and Technology of Dak Nong Province, Vietnam

${ }^{6}$ Co Ltd. NICO NICO Yasai

${ }^{7}$ Vietnam Geological Museum (VGM), General Department of Geology and Minerals of VN (GDGM)

Received 25 April 2018; Received in revised form 16 August 2018; Accepted 08 September 2018

\section{ABSTRACT}

The paper presents the initial results of the study of volcanic cave system and its typical formations in Krongno Volcano Geopark (KVG), Dak Nong, Vietnam. The volcanic caves have been discovered since 2007, under UNESCO sponsored the scientific project, are seen as unique geological heritages. The collaborative surveys and studies between Vietnamese geologists and the members of the Non-Profit Organization, Vulcanospeleological Society of Japan have discovered and surveyed 45 caves, and detailed mapping 20 caves. Using a complex of adequate methods, especially Remote Sensing image interpretation method, Surveying and mapping lava cave method, $\mathrm{K} / \mathrm{Ar}$ dating isotopic analytical method and Current methodology, the studies aim to affirm endogenous origin of the lava cave system, the formation mechanism, as well as the typical formations of the caves. Up to date, the lava caves and interior formation in lava caves in KVG have been examined and evaluated in term of geological nature and recognized as pillar geological heritages of the Geopark.

Keywords: Geological heritage; geopark; lava cave; lavacicle; primary, viscosity.

(C)2018 Vietnam Academy of Science and Technology

\section{Introduction}

Volcanic caves (lava caves) are preciously geological heritage resource that has been studied and conserved in many countries for centuries. For more than two decades, a number of volcanic caves have been discovered, explored, managed and conserved

"Corresponding author, Email: laphuc@gmail.com in Japan, South Korea, Hungary, Greece, Spain; the U.S.A, etc., with the aim for geotourism development within the limit of volcanic geo-parks or natural conservation areas (Barnabás, 2014; Bird et al., 2014; Cooper, Malcolm J.M., 2014; GakiPapanastassiou et al., 2014; Machado M., Lima E., 2014; Moreira et al., 2014; Nunes, João Caros, 2014a; Nunes, João Caros, 2014b; Patricia, Erfurt-Cooper, 2014). 
The prehistoric people were known to settle in Krongno volcanic caves thousands of years ago. For many years, Krongno local residents have frequented the caves to capture bats for food and their droppings for fertilizer. But they could not have realized the scientific values and the practical significance of the lava cave system.

With the aim to conserve geological heritages in Vietnam, between 2007 and 2008 thanks to the UNESCO financial support, geologists of Vietnam Geological Museum (VGM) conducted a research project entitled "Survey and study of geological heritages for geopark development and environmental protection in the Trinh $\mathrm{Nu}$ Waterfall area, $\mathrm{Cu}$ Jut, Dak Nong". The project achieved success in many aspects, including the discovery of volcanic caves and other geological heritage resources that serve as a background for the development of a geopark in the study area. One of the outcomes was the issuance of thousands of English-Vietnamese bilingual leaflets to promote recognition of geological heritage resources, including volcanic caves in the study area. Some members of the NPO Vulcano-Speleological Society of Japan (VSS) happened to obtain the information from the leaflets that subsequently led them to join the Vietnamese geologists in collaborative surveys and studies of volcanic caves in the Krongno district, Dak Nong province.

Since 2012, geologists from VGM and Vietnam National Museum of Nature (VNMN), Vietnam Academy of Science and Technology (VAST), have collaborated with the members of the NPO VSS to continue the survey of volcanic caves in Krongno. The Vietnam - Japan study collaboration has come to the conclusion that Krongno volcanic caves (lava caves) are the largest and unique in SE Asia (Laumanns M., 2013; Honda T., Tachihara H., 2015), and that they present the geological heritage resource, having a globally significant geological value, that appears as "the pillar" and "the soul" of KVG.

At present, the Krongno volcanic cave system is continually studied by two scientific and technological projects, include "Survey and study of geological heritages aim to develop a geological park in the Krongno area, Dak Nong" (2016-2018) funded by Dak Nong province, and "Survey and study of volcanic cave heritages with the aim to construct on-site conservation museums in The Central Highlands, taken lava caves in Krongno, Dak Nong province as an example (2017-2020)", under the Tay Nguyen Program of the 2016-2020 period. Both projects are operated by Vietnam National Museum of Nature (VNMN), Vietnam Academy of Science and Technology (VAST), as principal investigator. During the implementation of the two projects, in 2017, geologists of the VNMN (VAST) joined by archaeologists of the Institute of Archaeology and the Institute of Social Sciences of The Central Highlands (ISSCH) of Vietnam Academy of Social Science (VASS), discovered a series of prehistoric archaeological sites in the Krongno volcanic caves. In summary, studies of the Krongno volcanic cave system over years have identified valuable heritages in the fields of geology, biology, and culture (archaeology), which have been prepared for publication.

The paper aims to introduce distribution characteristics, origin, and formation mechanism of the lava cave system, as well as formation mechanism of some typical lava formations in the KVG lava caves.

The endogenous origin of the lava cave system, the typical lava formations, and their formation mechanism are preliminary results achieved by Vietnamese geologists and VSS's members of Japan. They are mentioned below as studying geoscientific result as well as main geological heritages for geo-tourism development of KVG. 
2. Basic literature, methodology, regional geology

\subsection{Basic literature}

The basic literature serving the study includes the topographic maps at scale 1:25.000 and 1:10.000, the geological map at scale 1:200.000 (Thang N.D. (Ed.), 1989) with supplements of survey note, satellite maps (Google Earth, Spots, Landsat) and Flycam images, among the above, field survey records collected since 2012 and sample analytical results are most essential (Honda T., Tachihara H., 2015).

\subsection{Methodology}

Volcanic caves are a special geological subject, which has only been studied in Vietnam since 2007. Volcanic caves do not expose in high mountain walls like limestone caves. Instead, they mostly occur deep underground. Lava cave entrances are normally subsided holes on the relatively flat basaltic floor, and many are covered by bushes, thick tropical vegetation. Therefore, they are commonly hard to discover. In order to discover and survey volcanic caves effectively, a series of methods and techniques are chosen, including: Inheritance data method; Remote Sensing image interpretation method; Sociological investigation method; Investigation, field survey, sample and literature collection method; $\mathrm{K} / \mathrm{Ar}$ dating isotopic analytical method; Statistical classification method; Professional discussion method; Information technology method; Surveying and mapping lava cave and Current methodology. However, there are four methods considered as most important and decisive, and briefly described as follows:

(i) Remote Sensing image interpretation method: Remote Sensing image interpretation method: Analyzing satellite and aerial images to interpret and discover the entrance of lava caves. Furthermore, the drone images are very effective in discovering lava caves, especially in dry season, when the plant cover almost disappear out of the surface. In the dry season, entrances of lava cave may be discovered by scattered and outstanding green dots on the yellowish-grey color background of basaltic rocks in the images.

(ii) Surveying and mapping lava cave method: Objectives of the cave surveying is to know the lava tube cave distribution, each direction relative to the eruption point (crater) by measuring the lava tube cave position and length in the KVG area and to know the structure of each lava tube cave by measuring the height width, slope angle and observing the inner structure of wall, ceiling and floor. The used instruments are for cave entrance location: GPS, for height, width and length inside the cave: laser distance measuring instrument, for slope angle of cave floor: inclination meter, for cave turning angle: protractor, for observation of the shape of the inner wall surface floor surface measurement by using calipers.

(iii) $\mathrm{K} / \mathrm{Ar}$ isotope dating method: This method is based on measurement of the product of the radioactive decay of the isotope of potassium (40K) into argon (40Ar). Potassium is a common element found in many rocks, including basaltic rocks. In basalts, no radiogenic $40 \mathrm{Ar}$ arising from the decay of $40 \mathrm{~K}$ in the mineral during its geological history has escaped by diffusion but starts to accumulate when the rock solidifies (recrystallizes). So the $\mathrm{K} / \mathrm{Ar}$ isotope dating method is considered as an effective method for basaltic rocks in the studying area.

(iv) Current methodology: Based on the study of current geological processes, such as volcanic eruptions and the formation of lava caves, those are taking place at present, for example, the volcanic processes in Hawaii, to interpret/explain similar processes happened in the geological past. The formation 
mechanism of many lava formations in the lava cave has been interpreted by using the method.

During field surveys, because of the limitation in professional technique and equipment, as well as lack of experience in field survey with regard to the Vietnamese members, collaboration with experienced Japanese VSS members in the study of volcanic caves appear to be very effective.

\subsection{Regional geology}

Quaternary basalts are observed largely in Tay Nguyen and offshore. They are original for richnesses natural resources in the region like basalt soil, gemstone and geological heritage (Bui et al., 2015). The volcanic caves occur in 4 communes, including Dak Sor, Nam Da, Buon Choa'h, and Dak Dro of the Krongno district, Dak Nong province. Outcropped geological formations in the area are simple, including sandstone, silt and siltstone belonging to $\mathrm{La}$ Nga Jurassic sedimentary formation, Xuan Loc Quaternary basalt and Quaternary loosen sediment (Figure 1).

The La Nga formation $\left(\mathrm{J}_{2} l n\right)$ : comprising mainly of terrigenous sediment, is widely spread in the western part of the study area (Figure 1) and is divided into three series (Thang N.D. (Ed.), 1989). Series 1 is composed of weathered gray siltstone, broken and turned into yellowish gray; black claystone with glassy shining plane intercalated by thin layers of yellow sandstone; and blackish gray siltstone, with a total thickness varying from 250 to $300 \mathrm{~m}$. Series 2 contains black siltstone, thinly layered, bearing a great number of idiomorphic pyrite crystals, intercalated with thin layers of clayish shale and white micabearing sandstone, having a total thickness of about $100 \mathrm{~m}$. Series 3 is comprising fine- to medium- grained gray, light gray and yellowish gray sandstone intercalated by gray, yellowish gray sandy siltstone along with several thin layers of claystone. The series 3 has about 350 to $400 \mathrm{~m}$ thick (Thang N.D. (Ed.), 1989).

The Xuan Loc formation $\left(\beta \mathrm{Q}_{1}{ }^{2} x l\right)$ : is distributed mainly in the center of the study area over an area of $73 \mathrm{~km}^{2}$, occupying most of the Buon Choa's commune and the lesser area in SE Dak Sor, west of Nam Da and NE Dak Dro. The formation is composed of Pleistocene basalt and is divided into three units. The lowest unit is made by black or dark-gray olivine basalt intercalated with some thin layers of basaltic pyroclasts and tuff. The basalt is mainly massive, some lesser amount is porous. This unit has a total thickness of about 45 to $51 \mathrm{~m}$. At some volcanic caves in southeastern $\mathrm{Chu} \mathrm{B}^{\prime} \mathrm{Luk}$ volcano and in the Dray Sap waterfall area, unit 1 basalt shows unconformable contact with La Nga sandstone and siltstone. Unit 2 is composed of massive olivine basalt, doleritic basalt, and plagiobasalt, making a total thickness of about 45 to $50 \mathrm{~m}$. Unit 3 consists of gray, dark-gray porous basalt, somewhere containing pyroclastic products such as gray tuff and volcanic ash. The total thickness of the unit is about $35 \mathrm{~m}$ (Thang N.D. (Ed.), 1989).

The Late Quaternary loosened formations $\left(\mathrm{Q}_{2}\right)$ : widely occur in the eastern part of the study area (Figure 1). They are comprised mainly of sandy clay, patchy silty clay and lateritic aggregates, occurred as loosen cumulates at low altitudes forming the first terrace along Serepok River, about 3 to $6 \mathrm{~m}$ high (relative to the river level) and about 5$6 \mathrm{~m}$ thick (Thang N.D. (Ed.), 1989). Along with large streams such as Dak DRo, Dak Sor, Chu Tac,... found are alluvial beds $\left(\mathrm{aQ}_{2}\right)$, consisted mostly of grayish yellow or grayish white, medium-to coarse-grained sand, having thickness varying from $0.2 \mathrm{~m}$ to $1 \mathrm{~m}$. The 
sediment of swamp origin $\left(\mathrm{bQ}_{2}\right)$ is also seen in small distribution area along narrow valleys at Buon Ol in Dak DRo commune, Nam Ha hamlet in Nam Da commune. The sediment is mainly clay, mud including lenses of finegrained, vegetation-rich sand.
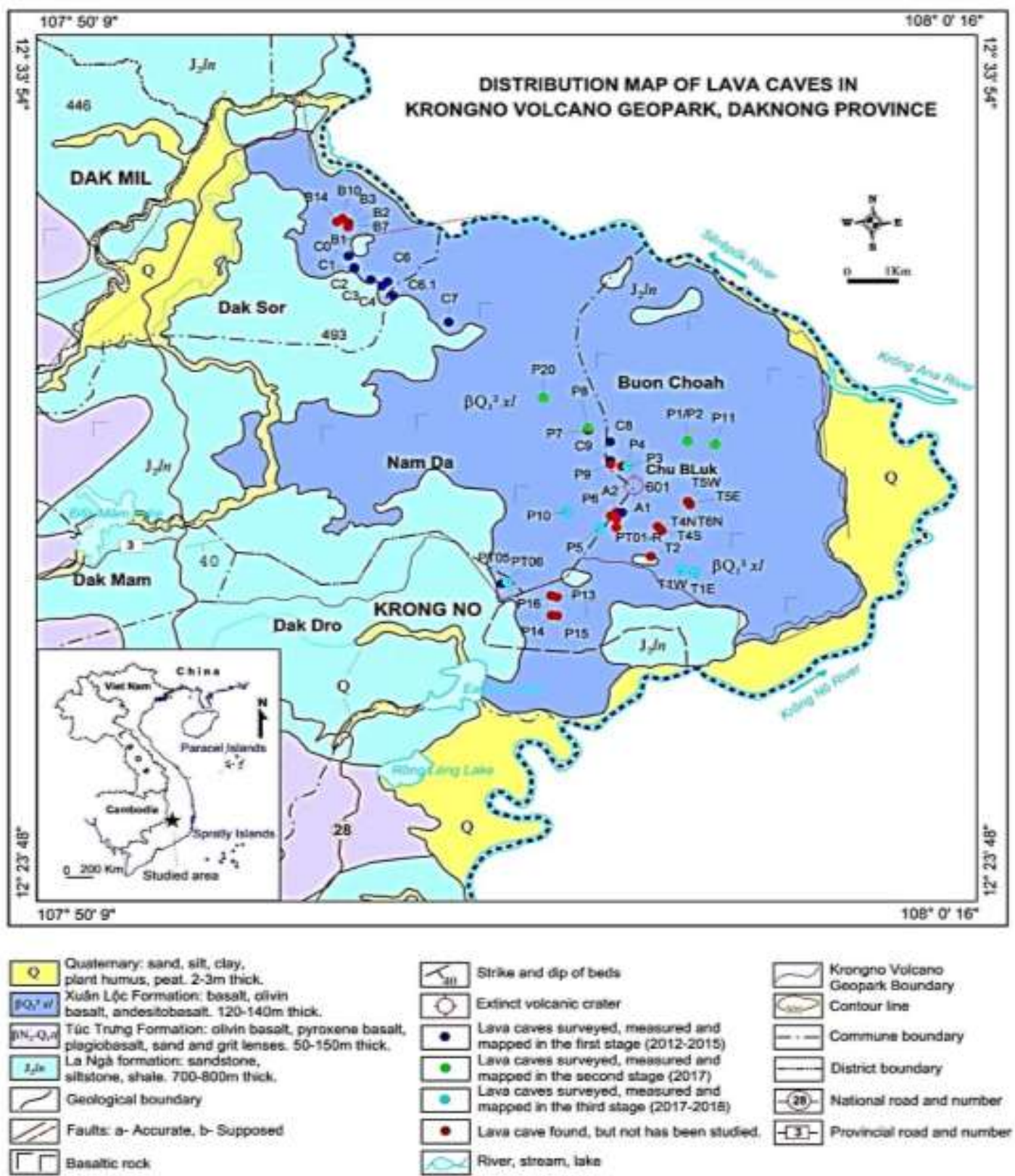

Figure 1. Distribution map of the lava caves in Krongno Volcano Geopark, Dak Nong

Tectonic faults: Satellite image shows major faults in the study area are subinterpretation combining with the field survey meridian, NW-SE and NE-SW oriented (Le et 
al., 2016). Sub-meridian faults are developed mainly in the Buon Choa'h area. Topographically expressed by the vertically steep wall the faults serve as the boundary between the basaltic formation and Quaternary sedimentary formation, on the one hand, and control the activity of Serepok River in the area, on the other. Besides, the sub-meridian fault in the center of the study area is expressed by the distribution of a belt of levees, running in the same fault direction. In the Dray Sap area also found are shearing marks on a clay layer of La Nga formation. Possibly, the sub-meridian fault may also serve as the main lava flow channel from $\mathrm{Chu}$ B'luk volcano.

\section{Lava caves}

\subsection{Distribution characteristics}

Krongno volcanic cave (lava cave) system is embedded entirely in the Xuan Loc basaltic formation, produced by the eruption of $\mathrm{Chu}$ B'Luk volcano (Figure 1). Forty-five caves having entrances large enough for an adult to go through have been discovered as of March 2018 , not to mention the others having much smaller, inaccessible entrances. Among the 45 certified caves, 20 have been comprehensively researched and mapped. Lengths of these caves vary from $81 \mathrm{~m}$ to $1066.5 \mathrm{~m}$, reaching the record length of SE Asian volcanic caves (Honda T., Tachihara H., 2015).

Volcanic caves scatter irregularly in different directions surrounding the $\mathrm{Chu}$ B'Luk volcano, reaching the farthest distance of $15 \mathrm{~km}$ northwest from the volcano (labeled as B), in Dak Sor commune. The volcanic caves normally aggregate as belt-formed, reflecting the lava flow direction, closely related to the eruption of Chu B'Luk volcano.

Depending on the groundwater level, the volcanic caves are divided into two types, dry and wet caves. The dry caves are above the current groundwater level, while the wet type is below the groundwater level, normally soaked with the water. The study up to date is mostly concentrated on the dry caves having entrances exposed to the surface. Those underground water level have not yet been explored and studied in three scientific fields, including geological, biological diversity, and cultural heritage as well.

Interpretation of topographic map, Flycam images in combination with the field survey documentation reveals a number of negative topographic relieves (funnel-shaped), having diameters varying between $10 \mathrm{~m}$ and $15 \mathrm{~m}$ and depths ranging from $3 \mathrm{~m}$ to $20 \mathrm{~m}$, aligned linearly. Subsided holes are filled with disorderly aligned basaltic boulders, indicating wall or ceiling collapse. Other holes contain elastically deformed basalt fragments, produced by the initial volcanic eruption. Whether the holes are collapsed cave roofs, forming secondary cave entrances now being buried, or small-scale volcanic craters of the Chu B'Luk volcanic system needed further detailed investigation.

\subsection{Lava cave entrances}

There are various forms of volcanic cave entrances in KVG, including tube-shaped, half-moon shaped, horizontal eclipsed, or smooth-angled triangle, etc.

Regarding origin, there are two types of entrance origin: primary (a type of skylight) and secondary (also called collapsed entrance) (Dave Bunnell, 2014). Primary entrances are normally steep and deep, formed by gas exhaust-explosion. Sizes of primary entrances are rather smaller and rounder (diameters varying between 3 and $7 \mathrm{~m}$ ) as compared with the second type. Some primary cave entrances are as deep as 25-26m (Figure 2a, b). Secondary entrance type was formed by the roof collapse, especially happened spacious caves with thin roofs. Most of Krongno volcanic caves have secondary entrances (Figure 3a, b). In many cases, primary entrances could be expanded larger due to the roof collapse as saw at the caves of $\mathrm{C} 7, \mathrm{~T} 1$, etc. 

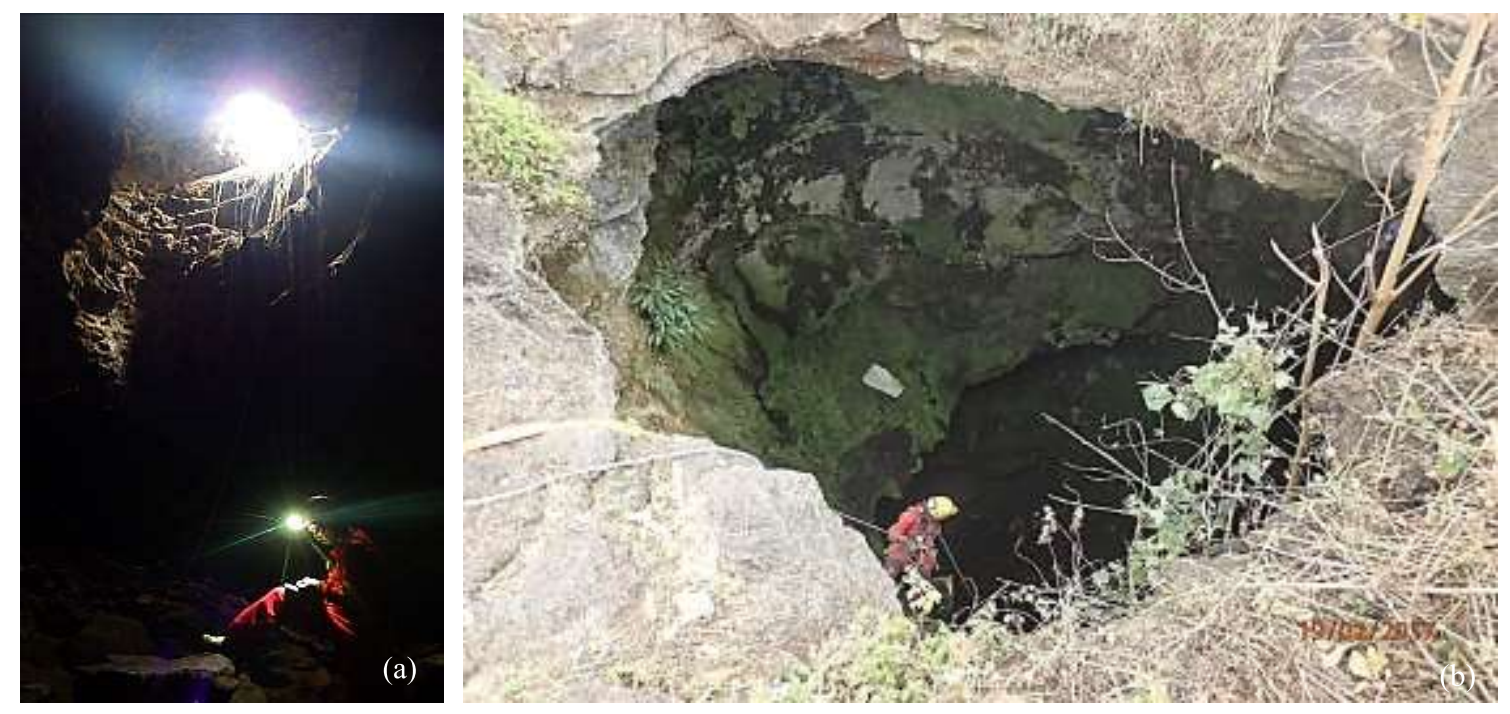

Figure 2. a) The primary entrance formed by gas exhaust-explosion of P8 cave;

b) The primary entrance formed by gas exhaust-explosion of P20 cave
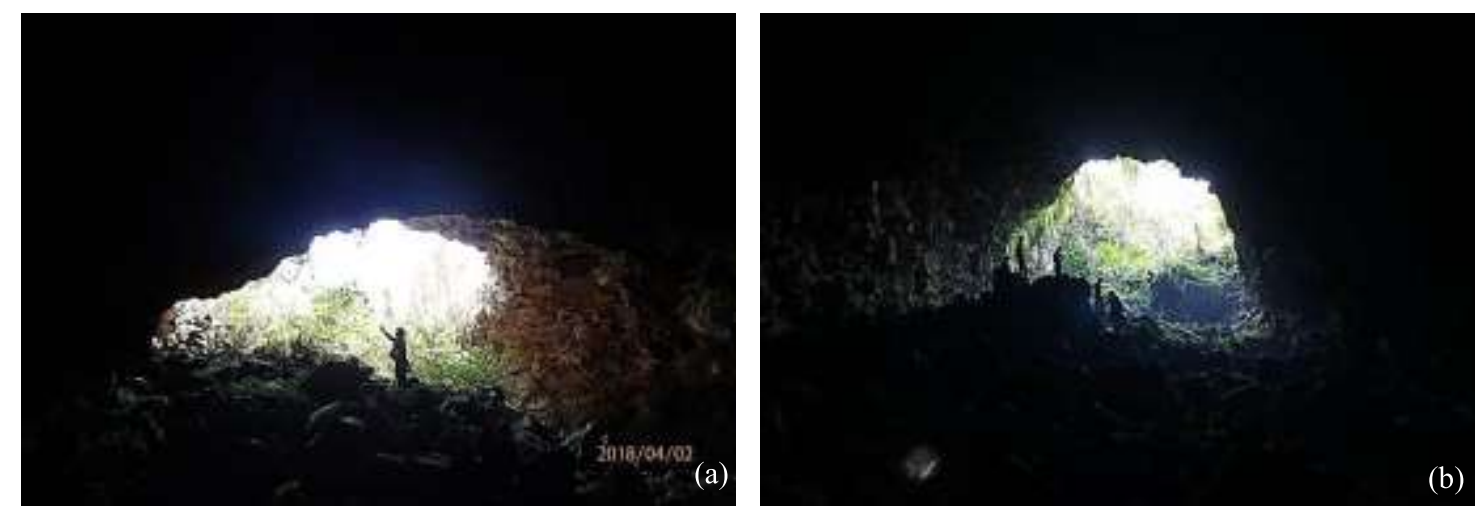

Figure 3. a) The secondary entrance of $\mathrm{C} 8$ cave due to the roof collapse;

b) The secondary entrance of $\mathrm{C} 9$ cave due to the roof collapse

\subsection{Cave length and depth characteristics}

Volcanic caves in KVG have lengths varying from tens to hundreds of meters, up to $1066.5 \mathrm{~m}$ as measured for cave C7 (Figure 4) (Table 1), the longest in SE Asia. At present, of the SE Asian volcanic caves, the longest $(\mathrm{C} 7-1066.6 \mathrm{~m})$, second $(\mathrm{C} 3+\mathrm{C} 4=967.8 \mathrm{~m})$ and third $(\mathrm{C} 8-791 \mathrm{~m})$ longest caves are those in KVG (Honda T., Tachihara H., 2015). A series of other caves in $\mathrm{KVG}$ also reach the impressive lengths such as P20: $568 \mathrm{~m}$; P11: 498.1m; C0: 475.5m; A1: 438.7m; $(\mathrm{C} 1+\mathrm{C} 2)$ :
$402 \mathrm{~m}$, etc. (Table 1).

In term of depth of volcanic caves at KVG, there is a large variation, from about $0.5 \mathrm{~m}$ to a few meters, in some cases, reaching tens of meters as observed for cave P8 and P20 in the northwest of Chu B'Luk volcano (Figure 1). Two caves P8 (26m deep) and P20 (25m deep) are considered as the deepest caves in KVG as well as in SE Asia (Table 1; Tachihara H., 2015). Thus, lava cave system in KVG is unique in both the length and the depth in SE Asia. 
La The Phuc, et al./Vietnam Journal of Earth Sciences 40 (2018)

Table 1. List of discovered volcanic caves in the Krongno area as of March 2018

\begin{tabular}{|c|c|c|c|c|c|c|c|}
\hline \multicolumn{8}{|c|}{ List of 20 volcanic caves surveyed and mapped } \\
\hline $\mathrm{N}^{0}$ & ID & Location & Longitude & Latitude & Length $(\mathrm{m})$ & $\operatorname{Depth}(\mathrm{m})$ & Entrance type \\
\hline 1 & $\mathrm{C} 0$ & Dak Sor & $107^{\circ} 53^{\prime} 32.87^{\prime \prime}$ & $12^{\circ} 31^{\prime} 18.69^{\prime \prime}$ & 475.5 & 14.9 & combined \\
\hline 2 & $\mathrm{C} 1$ & Dak Sor & $107^{\circ} 53^{\prime} 34.35^{\prime \prime}$ & $12^{\circ} 31^{\prime} 11.00^{\prime \prime}$ & \multirow{2}{*}{402.0} & \multirow{2}{*}{$3.5-4.5$} & secondary \\
\hline 3 & $\mathrm{C} 2$ & Dak Sor & $107^{\circ} 53^{\prime} 35.39^{\prime \prime}$ & $12^{\circ} 31^{\prime} 10.04 "$ & & & secondary \\
\hline 4 & $\mathrm{C} 3$ & Dak Sor & $107^{\circ} 53^{\prime} 47.24^{\prime \prime}$ & $12^{\circ} 31^{\prime} 2.35^{\prime \prime}$ & 716.3 & 7.3 & secondary \\
\hline 5 & $\mathrm{C} 4$ & Dak Sor & $107^{\circ} 53^{\prime} 52.28^{\prime \prime}$ & $12^{\circ} 30^{\prime} 57.91 "$ & 251.5 & $9-10$ & secondary \\
\hline 6 & C6 & Dak Sor & $107^{\circ} 53^{\prime} 57.02^{\prime \prime}$ & $12^{\circ} 31^{\prime} 0.91^{\prime \prime}$ & 180.3 & 4.3 & secondary \\
\hline 7 & C6.1 & Nam Da & $107^{\circ} 53^{\prime} 59.76^{\prime \prime}$ & $12^{\circ} 30^{\prime} 51.23^{\prime \prime}$ & 293.7 & 4.6 & secondary \\
\hline 8 & $\mathrm{C} 7$ & Nam Da & $107^{\circ} 54^{\prime} 35.12^{\prime \prime}$ & $12^{\circ} 30^{\prime} 32.47^{\prime \prime}$ & 1066.5 & $15-20$ & combined \\
\hline 9 & $\mathrm{C} 8$ & Buon Choa'h & $107^{\circ} 56^{\prime} 19.20^{\prime \prime}$ & $12^{\circ} 29^{\prime} 8.53^{\prime \prime}$ & 791.0 & 23.8 & secondary \\
\hline 10 & C9 & Buon Choa'h & $107^{\circ} 56^{\prime} 20.03^{\prime \prime}$ & $12^{\circ} 28^{\prime} 55.59^{\prime \prime}$ & 217.0 & 22.6 & combined \\
\hline 11 & $\mathrm{P} 1, \mathrm{P} 2$ & Buon Choa'h & $107^{\circ} 57^{\prime} 10.14^{\prime \prime}$ & $12^{\circ} 29^{\prime} 8.57^{\prime \prime}$ & 530.5 & $15-18$ & secondary \\
\hline 12 & P8 & Nam Da & $107^{\circ} 56^{\prime} 5.74^{\prime \prime}$ & $12^{\circ} 29^{\prime} 18.07^{\prime \prime}$ & 344.1 & 26 & primary \\
\hline 13 & P11 & Buon Choa'h & $107^{\circ} 57^{\prime} 28.24^{\prime \prime}$ & $12^{\circ} 29^{\prime} 5.97^{\prime \prime}$ & 498.1 & $7-9$ & secondary \\
\hline 14 & P20 & Nam Da & $107^{\circ} 55^{\prime} 37.67^{\prime \prime}$ & $12^{\circ} 29^{\prime} 39.58^{\prime \prime}$ & 568.0 & 25 & primary \\
\hline 15 & $\mathrm{~A} 1$ & Buon Choa'h & $107^{\circ} 56^{\prime} 28.73^{\prime \prime}$ & $12^{\circ} 28^{\prime} 19.67^{\prime \prime}$ & 438.7 & 10 & combined \\
\hline 16 & $\mathrm{P} 3$ & Buon Choa'h & $107^{\circ} 56^{\prime} 32.87^{\prime \prime}$ & $12^{\circ} 28^{\prime} 51.52^{\prime \prime}$ & 81.0 & 5 & secondary \\
\hline 17 & P5 (PT07) & Buon Choa'h & $107^{\circ} 56^{\prime} 13.01^{\prime \prime}$ & $12^{\circ} 28^{\prime} 8.86^{\prime \prime}$ & 204 & 4.2 & secondary \\
\hline 18 & $\begin{array}{l}\text { P10E } \\
\text { P10W }\end{array}$ & Nam Da & $\begin{array}{l}107^{\circ} 55^{\prime} 54.22^{\prime \prime} \\
107^{\circ} 55^{\prime} 52.45^{\prime \prime}\end{array}$ & $\begin{array}{l}12^{\circ} 28^{\prime} 20.06^{\prime \prime} \\
12^{\circ} 28^{\prime} 20.82^{\prime \prime}\end{array}$ & 160 & 4.5 & secondary \\
\hline 19 & PT06 & Dak Dro & $107^{\circ} 55^{\prime} 16.68^{\prime \prime}$ & $12^{\circ} 27^{\prime} 28.62^{\prime \prime}$ & 200 & 5 & secondary \\
\hline 20 & T1W & Buon Choa'h & $107^{\circ} 57^{\prime} 6.264^{\prime \prime}$ & $12^{\circ} 27^{\prime} 39.02^{\prime \prime}$ & 303.1 & 16 & combined \\
\hline \multirow{2}{*}{\multicolumn{5}{|c|}{$\begin{array}{c}\text { Total length of } 20 \text { volcanic caves surveyed and mapped } \\
\text { List of } 25 \text { volcanic caves discovered not detailed surve }\end{array}$}} & 7721.3 & & \\
\hline \multicolumn{4}{|c|}{ List of 25 volcanic caves discovered, not detailed surveyed and mapped } & & & & \\
\hline 21 & A2 & Buon Choa'h & $107^{\circ} 56^{\prime} 24.22^{\prime \prime}$ & $12^{\circ} 28^{\prime} 19.96 "$ & & & \\
\hline 22 & PT01-R & Buon Choa'h & $107^{\circ} 56^{\prime} 23.52^{\prime \prime}$ & $12^{\circ} 28^{\prime} 15.38^{\prime \prime}$ & & & \\
\hline 23 & PT05 & Dak Dro & $107^{\circ} 55^{\prime} 7.99^{\prime \prime}$ & $12^{\circ} 27^{\prime} 31.50^{\prime \prime}$ & & & \\
\hline 24 & T1E & Buon Choa'h & $107^{\circ} 57^{\prime} 7.44^{\prime \prime}$ & $12^{\circ} 27^{\prime} 41.51^{\prime \prime}$ & & & \\
\hline 25 & B1 & Dak Sor & $107^{\circ} 53^{\prime} 32.72^{\prime \prime}$ & $12^{\circ} 31^{\prime} 35.34^{\prime \prime}$ & & & \\
\hline 26 & B7 & Dak Sor & $107^{\circ} 53^{\prime} 32.82^{\prime \prime}$ & $12^{\circ} 31^{\prime} 40.68^{\prime \prime}$ & & & \\
\hline 27 & B2 & Dak Sor & $107^{\circ} 53^{\prime} 32.30^{\prime \prime}$ & $12^{\circ} 31^{\prime} 41.65^{\prime \prime}$ & & & \\
\hline 28 & B3 & Dak Sor & $107^{\circ} 53^{\prime} 30.32^{\prime \prime}$ & $12^{\circ} 31^{\prime} 41.71^{\prime \prime}$ & & & \\
\hline 29 & $\mathrm{~B} 10$ & Dak Sor & $107^{\circ} 53^{\prime} 28.05^{\prime \prime}$ & $12^{\circ} 31^{\prime} 44.91^{\prime \prime}$ & & & \\
\hline 30 & B14 & Dak Sor & $107^{\circ} 53^{\prime} 22.64^{\prime \prime}$ & $12^{\circ} 31^{\prime} 42.49^{\prime \prime}$ & & & \\
\hline 31 & $\mathrm{P} 4$ & Buon Choa'h & $107^{\circ} 56^{\prime} 26.64^{\prime \prime}$ & $12^{\circ} 28^{\prime} 51.57^{\prime \prime}$ & & & \\
\hline 32 & P6 & Buon Choa'h & $107^{\circ} 56^{\prime} 27.20^{\prime \prime}$ & $12^{\circ} 28^{\prime} 17.57^{\prime \prime}$ & & & \\
\hline 33 & P7 & Nam Da & $107^{\circ} 56^{\prime} 5.84^{\prime \prime}$ & $12^{\circ} 29^{\prime} 16.87^{\prime \prime}$ & & & \\
\hline 34 & P9 & Buon Choa'h & $107^{\circ} 56^{\prime} 21.40^{\prime \prime}$ & $12^{\circ} 28^{\prime} 53.09^{\prime \prime}$ & & & \\
\hline 35 & P13 & Buon Choa'h & $107^{\circ} 55^{\prime} 42.94^{\prime \prime}$ & $12^{\circ} 27^{\prime} 21.57^{\prime \prime}$ & & & \\
\hline 36 & P14 & Buon Choa'h & $107^{\circ} 55^{\prime} 42.54^{\prime \prime}$ & $12^{\circ} 27^{\prime} 8.97^{\prime \prime}$ & & & \\
\hline 37 & P15 & Buon Choa'h & $107^{\circ} 55^{\prime} 46.04^{\prime \prime}$ & $12^{\circ} 27^{\prime} 8.67^{\prime \prime}$ & & & \\
\hline 38 & $\mathrm{P} 16$ & Buon Choa'h & $107^{\circ} 55^{\prime} 42.44^{\prime \prime}$ & $12^{\circ} 27^{\prime} 22.77^{\prime \prime}$ & & & \\
\hline 39 & $\mathrm{~T} 2$ & Buon Choa'h & $107^{\circ} 56^{\prime} 39.54^{\prime \prime}$ & $12^{\circ} 27^{\prime} 52.67^{\prime \prime}$ & & & \\
\hline 40 & T3 & Buon Choa'h & $107^{\circ} 56^{\prime} 17.24^{\prime \prime}$ & $12^{\circ} 28^{\prime} 12.97^{\prime \prime}$ & & & \\
\hline 41 & T4N & Buon Choa'h & $107^{\circ} 56^{\prime} 44.24^{\prime \prime}$ & $12^{\circ} 28^{\prime} 13.27^{\prime \prime}$ & & & \\
\hline 42 & T4S & Buon Choa'h & $107^{\circ} 56^{\prime} 46.55^{\prime \prime}$ & $12^{\circ} 28^{\prime} 10.47^{\prime \prime}$ & & & \\
\hline 43 & T5W & Buon Choa'h & $107^{\circ} 57^{\prime} 4.14^{\prime \prime}$ & $12^{\circ} 28^{\prime} 30.37^{\prime \prime}$ & & & \\
\hline 44 & T5E & Buon Choa'h & $107^{\circ} 57^{\prime} 5.04^{\prime \prime}$ & $12^{\circ} 28^{\prime} 29.27^{\prime \prime}$ & & & \\
\hline 45 & T6N & Buon Choa'h & $107^{\circ} 57^{\prime} 5.54^{\prime \prime}$ & $12^{\circ} 28^{\prime} 28.17^{\prime \prime}$ & & & \\
\hline
\end{tabular}




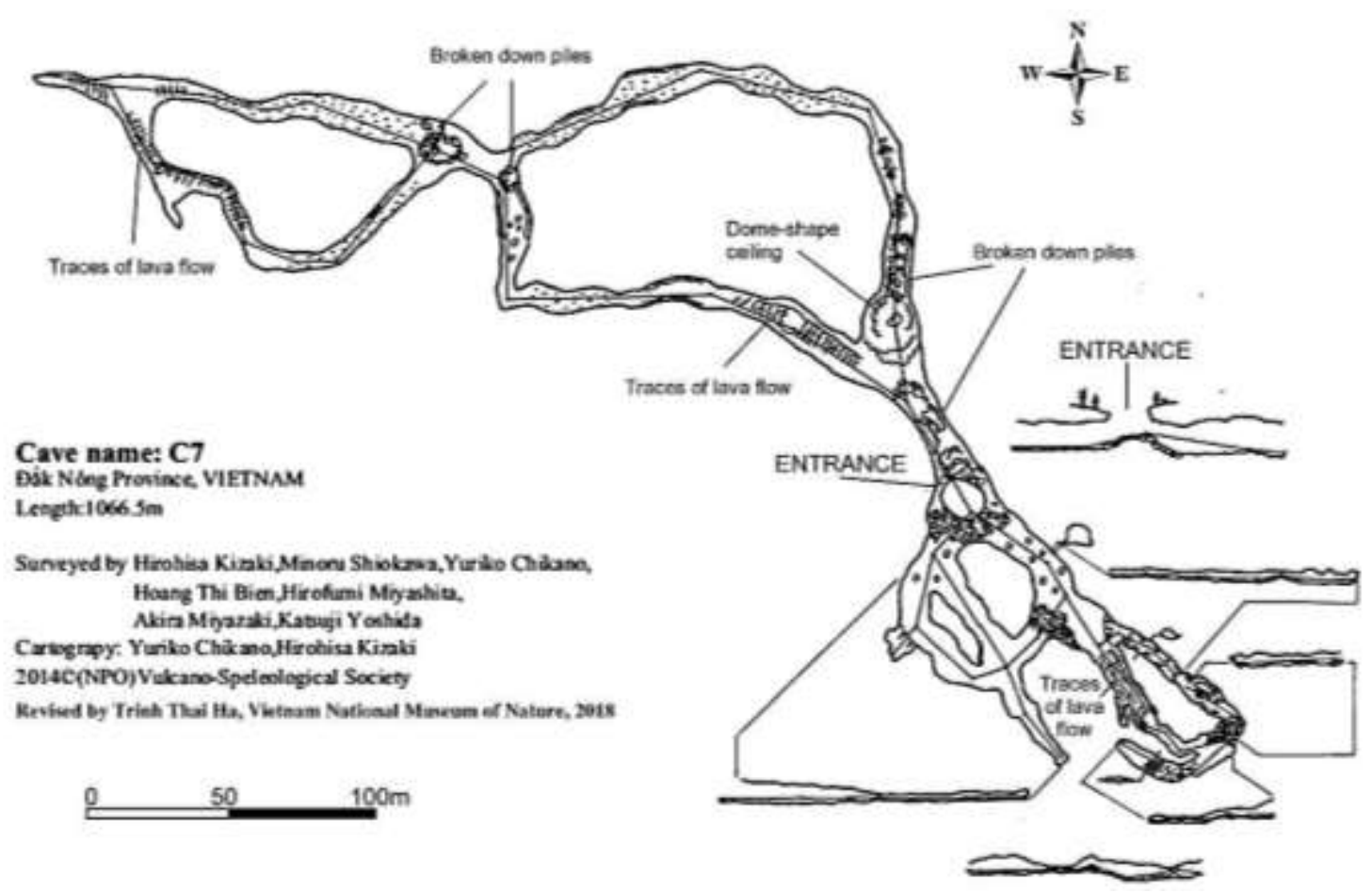

Figure 4. The C7 map

\subsection{Lava cave branched and floored features}

Branching among the volcanic caves at $\mathrm{KVG}$ is common. Cave branching and flooring happened from simple to complex. The open angle and distance between branches are controlled by the surface morphology. The smoother surface the larger branching open angle (for example, cave $\mathrm{C} 7$ ). The narrower and lower surface (valley), the rarer branching activity and the smaller open angle.

Krongno volcanic caves are complex in terms of their distribution, width, and depth. While some caves occur as one-floored such as $\mathrm{C} 8, \mathrm{C} 9, \mathrm{P} 11$, etc., there are caves having two or even three floors such as $\mathrm{A} 1$ or $\mathrm{C} 0$ (Figure 5).

A comprehensive study of the distribution and structural characteristics of the volcanic caves should shed light on the relationship between geochemical composition, hydrodynamics of lava flow, paleogeomorphology and regional tectonic activity. However, these topics will be addressed in a later report.

\subsection{Typical formations in KVG lava caves}

Each formation in a lava cave reflects information on the cave formation mechanism, lava flow episode and rate, lava physio-chemical and hydrodynamic properties. The interior formation may also reflect the lava flow direction, interaction among lava flows and the surrounding environment, etc. (Dave Bunnell, 2014; Larson C.V., 1991).

\subsubsection{Lava flow marks}

Lava flow marks are evidence of lava flows running in the lava tube in the past and could be seen in almost lava caves in KVG. The marks on the walls reflect the number of lava flows or eruption episodes having been through the cave tube over time. Some KVG caves show 4 or 5 level marks such as $\mathrm{C} 2$, C6.1, C7, etc. (Figure 6a, b), while others show 1 or 2 level marks, such as $\mathrm{C} 1$; $\mathrm{C} 2$. Also, lava flow marks on cave floor present lava flow directions have been seen in many caves (Figure 7a, b). 
La The Phuc, et al./Vietnam Journal of Earth Sciences 40 (2018)

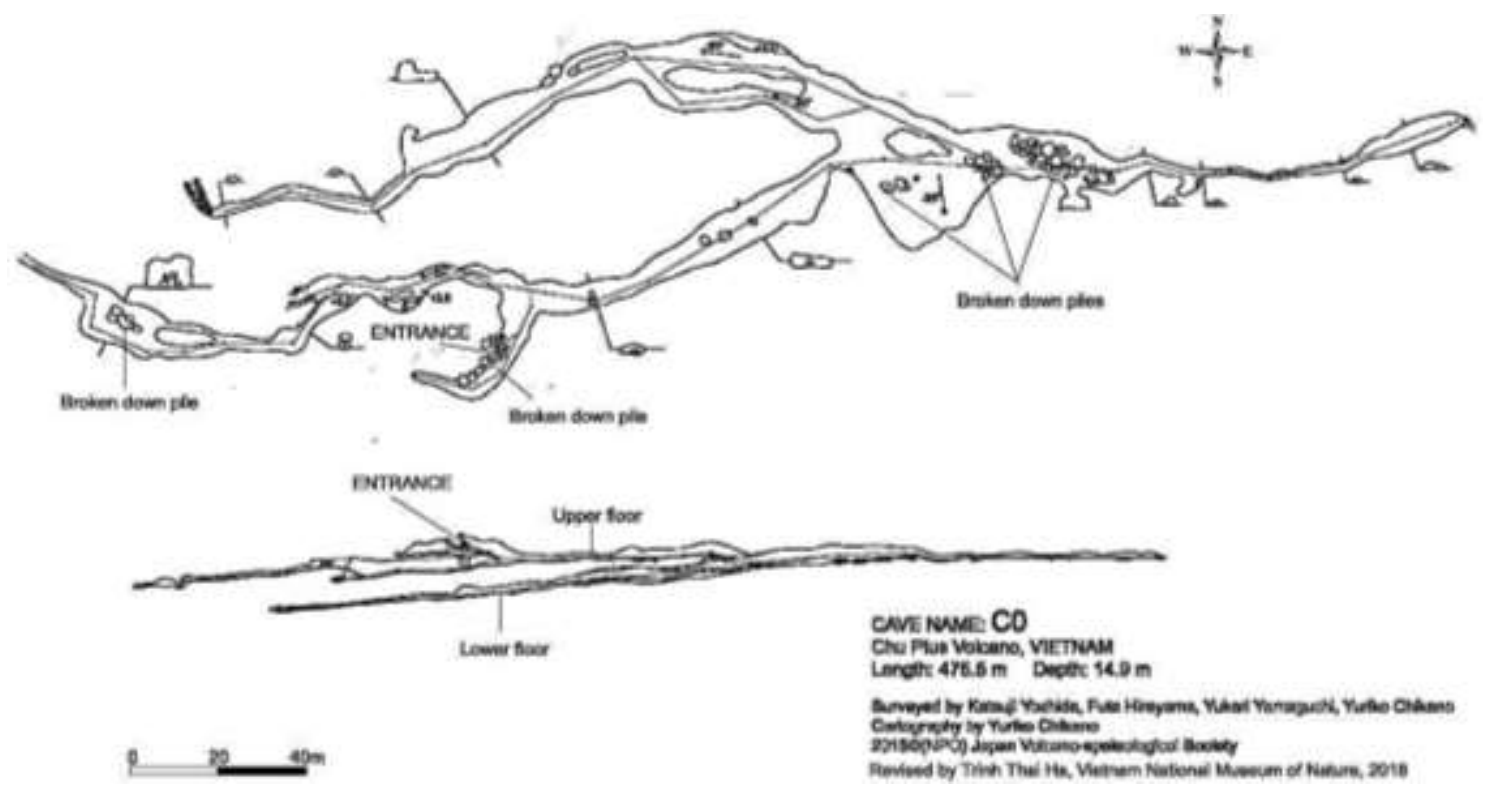

Figure 5. The C0 map
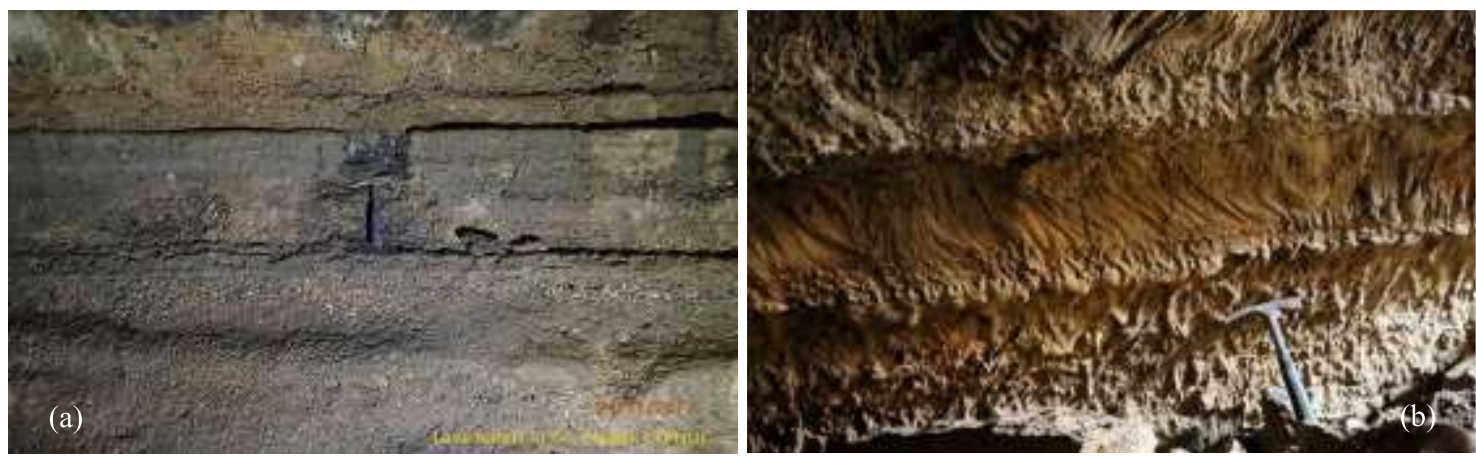

Figure 6. a) Lava level marks in the up-stream of $\mathrm{C} 2$ cave; b) Lava level marks in the down-stream of $\mathrm{C} 2$ cave
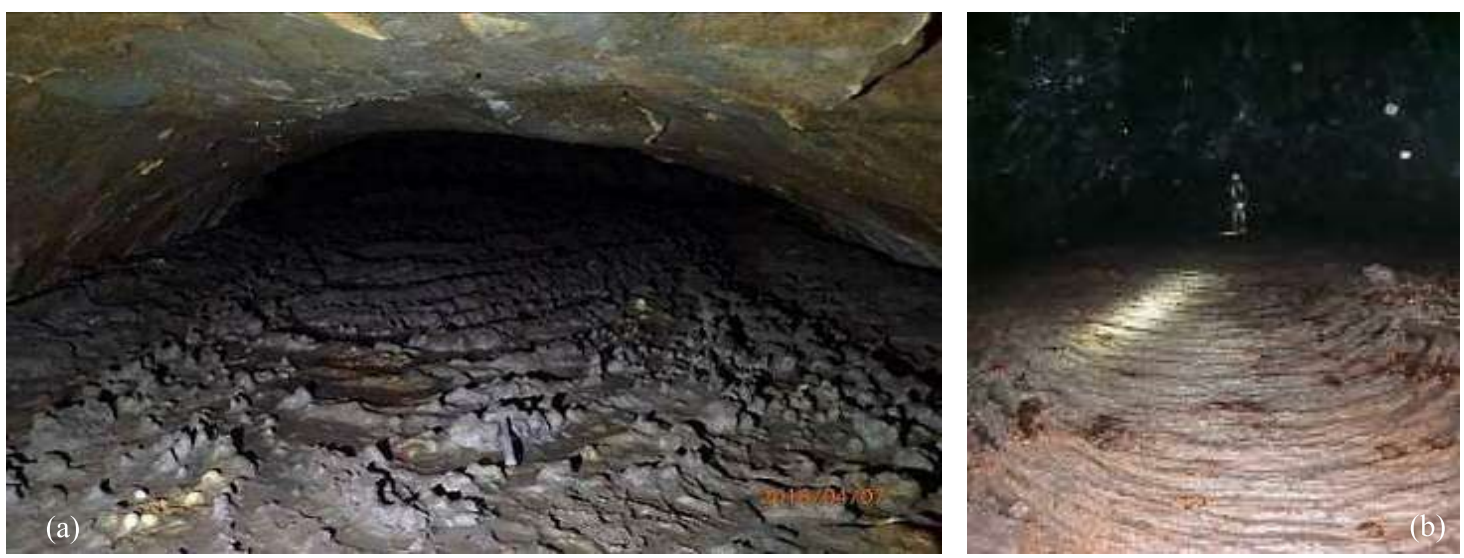

Figure 7. a) Lava flow direction in P11 cave (a 279mm long Estwing hammer's on the floor as a scale); b) Lava flow direction in ropy-shape in $\mathrm{C} 7$ cave. (a standing $1.7 \mathrm{~m}$ tall person as a scale) 


\subsubsection{Linings}

When lava flows continuously pass through a previously formed cave tube, depending on the level of previous lava flows part of the lava would line on the wall or even the ceiling, forming cave's interior linings (Dave Bunnell 2014; Larson C.V., 1991). On the surface of linings often developed are dark colored lavacicles (lava stalactites) and enamel covers. Linings are common in volcanic caves at KVG. Depending on the mass of a lava flow and residence time in the lava tube, linings can be variously thin (Figure $8 \mathrm{a}$ ) or very thick (Figure $8 \mathrm{~b}$ ). Due to the difference in cohesive property between the tube wall and the interior linings, the latter can be easily peeled off and fallen down, scroll and become a scroll-pipe such as saw in T1 cave (Figure 8c, d). Therefore, the study of linings may reveal volcanic eruption episodes which closely related to the cave formation.
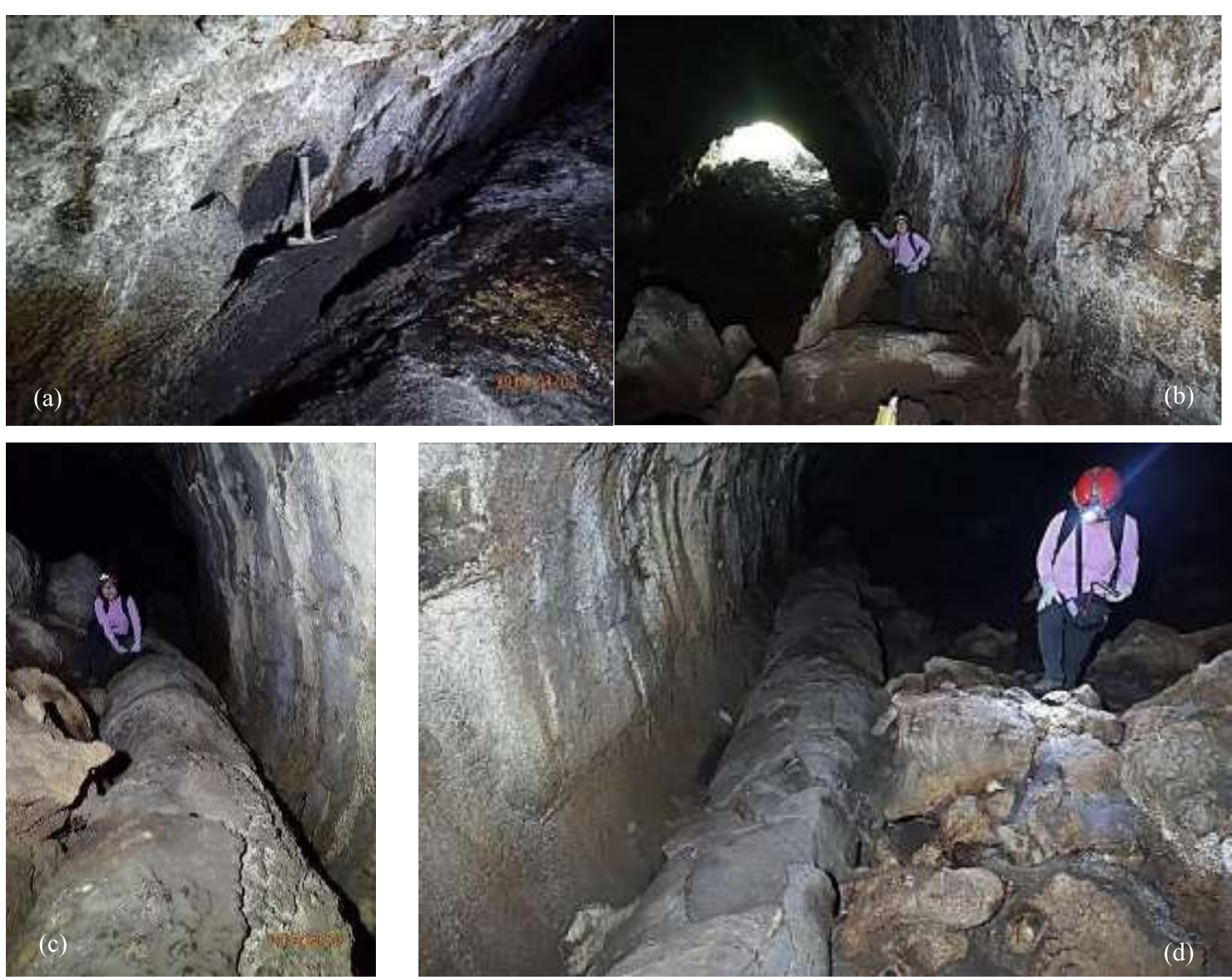

Figure 8. a) The ultra-thin linings in C8 cave (a $279 \mathrm{~mm}$ long Estwing hammer's on the wall as a scale); b) The linings in $\mathrm{C} 9$ cave reach to the maximum $80 \mathrm{~cm}$ thick (a standing $1.55 \mathrm{~m}$ tall geologist as a scale; c, d. The unique linings as scroll water-pipe in T1 cave

\subsubsection{Lava shelves}

The shelves are elongate, overhanging crust, remnants of a crust, or accumulation of lining attached to a lava tube wall. In many cases, they present as overhanging linings that were not washed away by later lava flows (Larson C.V., 
1991). There is the number of lava shelves in Therefore, interior lava shelves are related to volcanic caves in KVG (Figure 9a, b). linings from which they were formed.
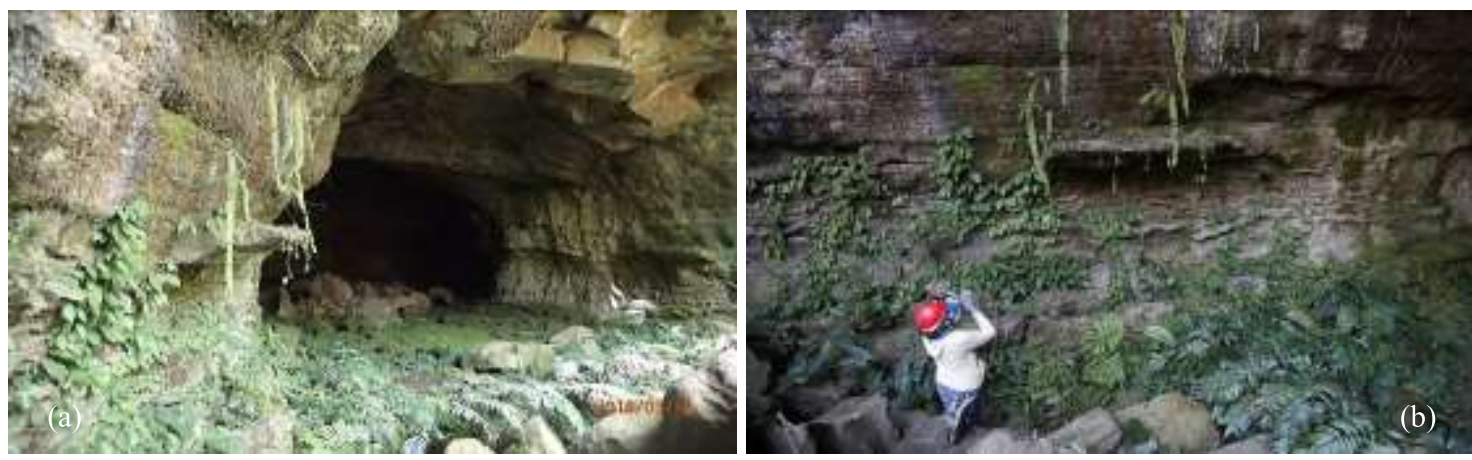

Figure 9. a) Lava shelf in C6.1 cave (right wall); b) Lava shelves in C6.1 cave (geologist and ordinary plants in the picture such as ferns as natural scales)

\subsubsection{Lava levees}

When a hot lava flow moves through an existing lava tube, two sides tend to cool first so create a free-standing vertical remnant along the tube edges. They are called "lava levees" of lava caves. The levee height is often increased by splashing of the lava flow, so the top is often irregular. The inside edge of the levee is typically smooth but may show traces of lava flow. Levees often are associated with gutters, which form between the levee and the tube wall (Dave Bunnell, 2014; Larson C.V., 1991). Levees are widespread in caves of KVG such as in C6.1; C6', T1 caves, etc. (Figure 10a, b).
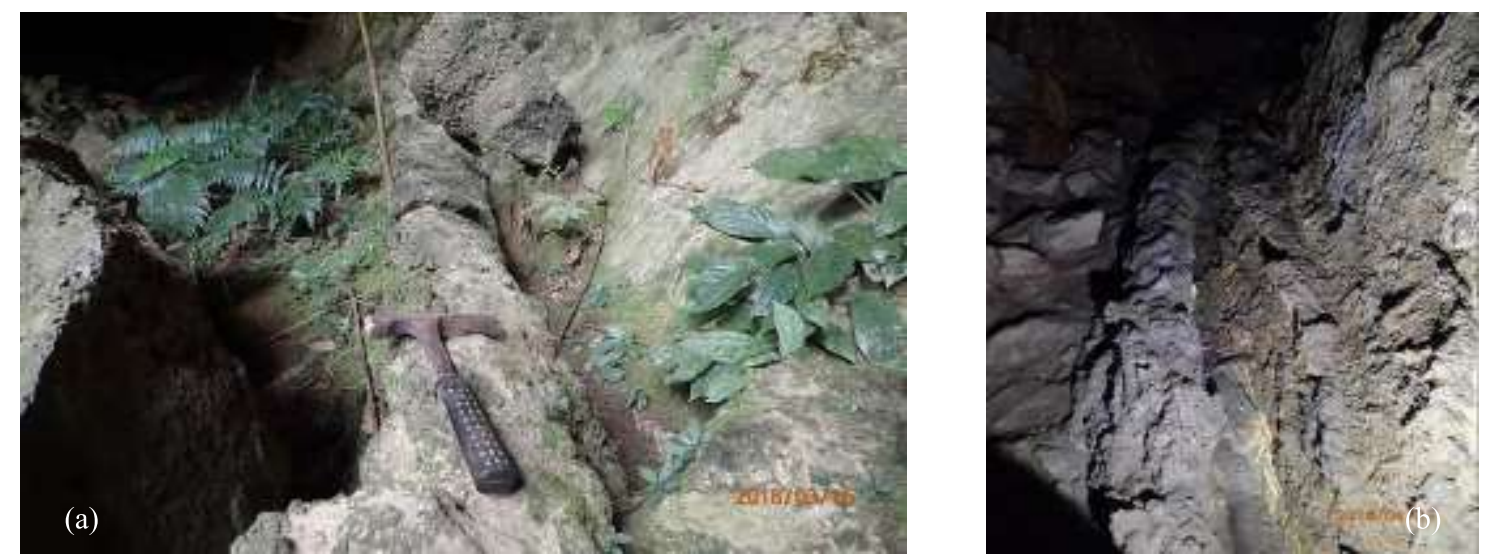

Figure 10. a) Lava levee in C6.1 cave (a $279 \mathrm{~mm}$ long Estwing hammer's inside as a scale); b) Levee in T1 cave (a $279 \mathrm{~mm}$ long Estwing hammer's on the wall as a scale)

\subsubsection{Lava balls}

Lava balls are actually cooled lava blocks, bounders, or fragments fallen from the ceiling on to a running lava flow in a lava tube, thus being rolled away. During the rolling process, the fallen boulders were added layers of hot lava to their outer crust. The rocks then gradually cooled, hardened and glued to the cave floor (Dave Bunnell, 2014); Larson C.V., 1991). Lava balls having various forms and shapes are encountered in many lava tube caves in KVG (Figure 11a, b). 
Vietnam Journal of Earth Sciences, 40(4), 299-320
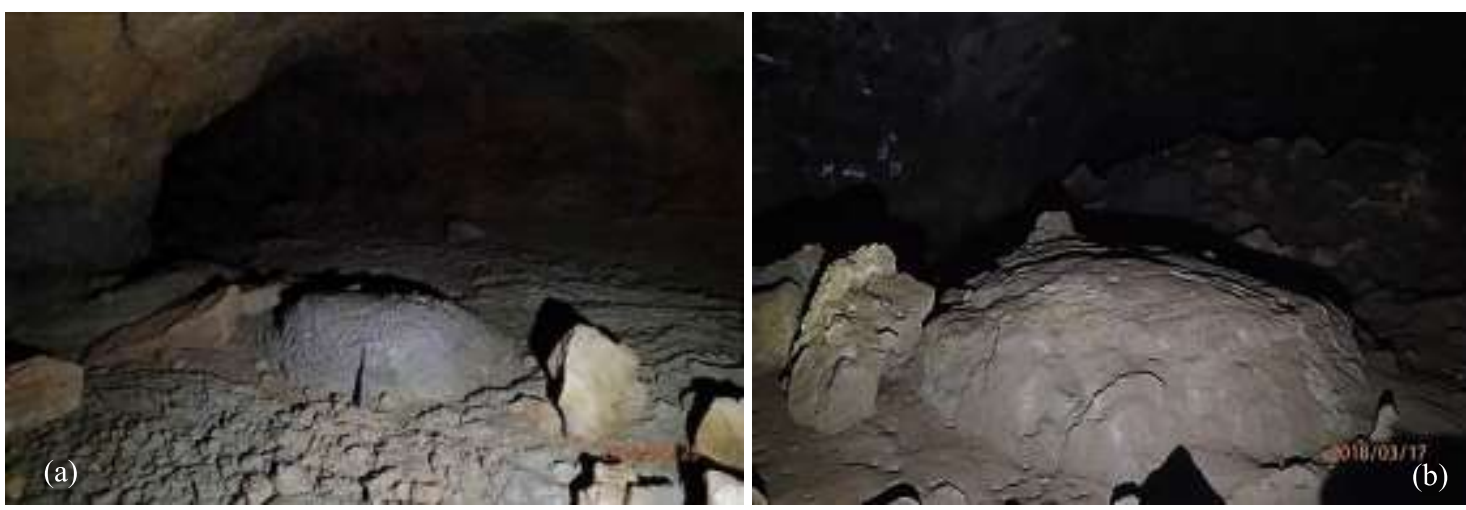

Figure 11. a) Lava ball in C0 cave (a 279mm long Estwing hammer's in the pictutre as a scale);

b) Lava ball in a tortoise-shape (about $1.5 \mathrm{~m}$ high) in C6.1 cave

\subsubsection{Lava windows and lava seals}

Lava windows are those to connect lava floors or branches within a lava tube. Normally, lava flows passing through windows in the low land would leave marks as levees or thin layers of lava covering rims

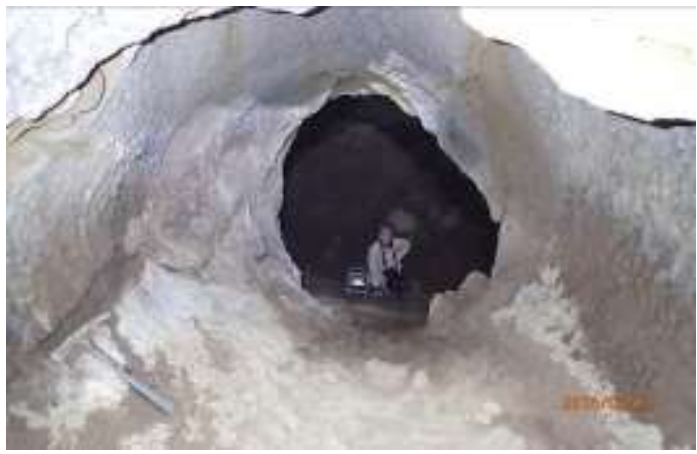

Figure 12. Lava window in C2 cave (a $279 \mathrm{~mm}$ long Estwing hammer's in the left as a scale)

\subsubsection{Lava falls}

Lava falls are remnants of later lava flows running through cooled lava windows or skylights before pouring down the cave floor (Dave Bunnell, 2014; Larson, CV., 1991). (Figure 14a, b) part of lava fall could be pushed away by running lava flows from below as found in cave $\mathrm{T} 1 ; \mathrm{C} 2$, etc.

\subsubsection{Lava lakes}

When a massive lava flow pouring down a of the windows (Dave Bunnell, 2014; Larson C.V., 1991). However, if windows being jammed by lava they become lava seals (Dave Bunnell, 2014; Larson, CV., 1991). Lava windows and lava seals are commonly observed in volcanic caves at KVG (Figure $12,13)$.

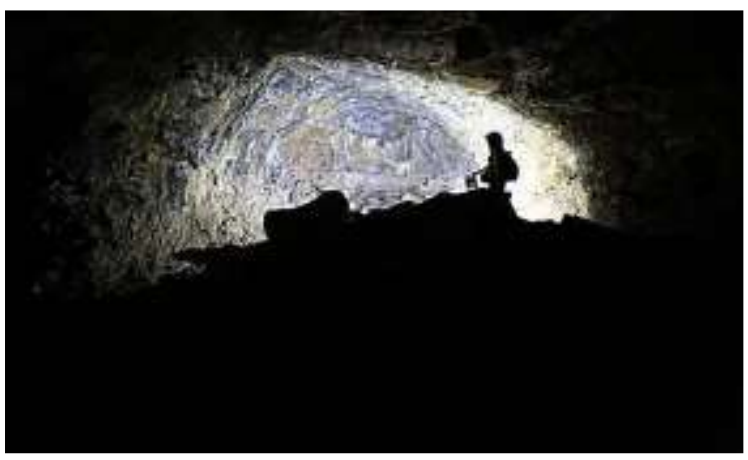

Figure 13. Lava seal in $\mathrm{C} 3$ with a geologist as a scale

low land it would cumulate, gradually cool and constrict to form a lava lake with a concentric cracking system on the surface (Dave Bunnell, 2014; Larson C.V., 1991). A large lava lake with a diameter of about $15 \mathrm{~m}$ is found at the downstream of cave T1 (Figure 15). Since the topographic surface of Chu B'Luk volcanic area is relatively flat, finding a lava lake such that in cave $\mathrm{T} 1$ is uniquely rare within the KVG. 
La The Phuc, et al./Vietnam Journal of Earth Sciences 40 (2018)
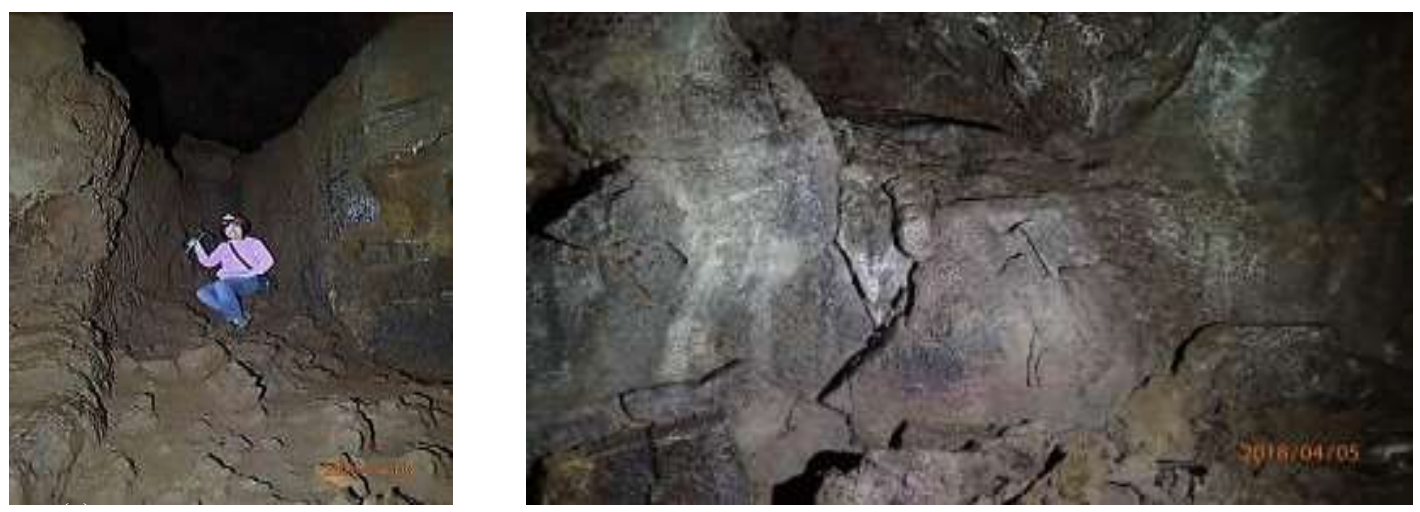

Figure 14. a) Lava-fall in P5 cave; b) Lava-fall in A1 cave
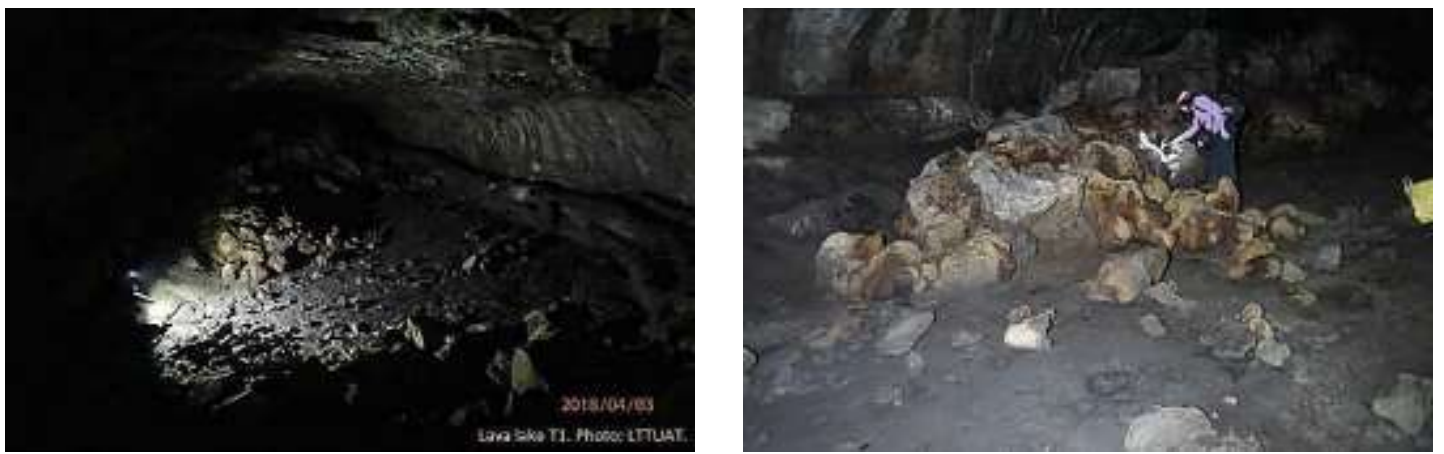

Figure 15. Lava lake in $\mathrm{T} 1$ cave

\subsubsection{Skylights}

There are two types of skylights at $\mathrm{KVG}$, primary and secondary. The primary skylight is resulted by gas-exhaust channel. Primary skylights usually circle-shaped, located in the center of cave's ceiling. The ceiling surrounding a skylight is observed with remnants of vertical lava columns starting from the floor (Figure 16a); primary lavacicles normally point to the direction of decreasing pressure/gas-exhaust.

Secondary skylight is a result of roof collapse due to the thin and weak ceiling or "cupolars" of lava cave. Almost skylights in KVG are the second type (Figure 16b).
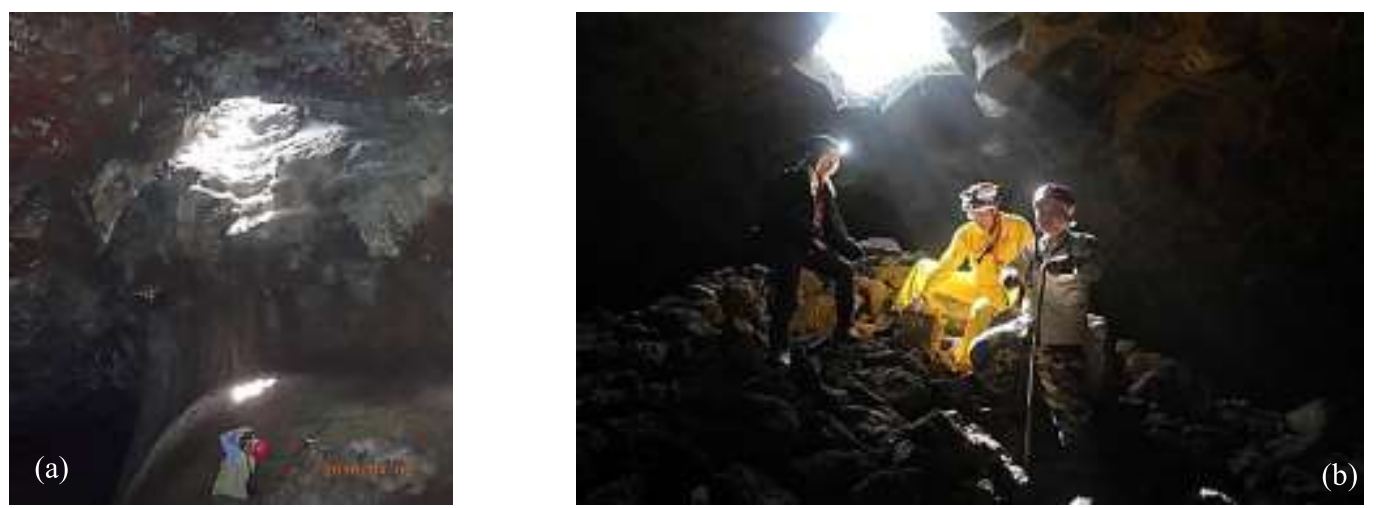

Figure 16. a) The original skylight in $\mathrm{C} 8$ cave (The standing geologist as a scale); b) The secondary skylight in C6 cave 
Vietnam Journal of Earth Sciences, 40(4), 299-320

\subsubsection{Contraction cracks and tectonic fractures}

Contraction cracks are abundant and have been found on ceilings, walls or floors of lava caves in KVG (Figure 17a). They caused by contraction of lava as it flows and cools (Larson C.V., 1991). Usually, cracks caused by a contraction in the ceiling are polygonshaped, while those on the wall and floor are linear, and cracks in lava lakes such as in T1 cave, are concentric. Fractures being stably developed, elongated in one direction and cut through all formations in the cave are linked to tectonic activity occurred after the cave had long been formed (Figure 17b).
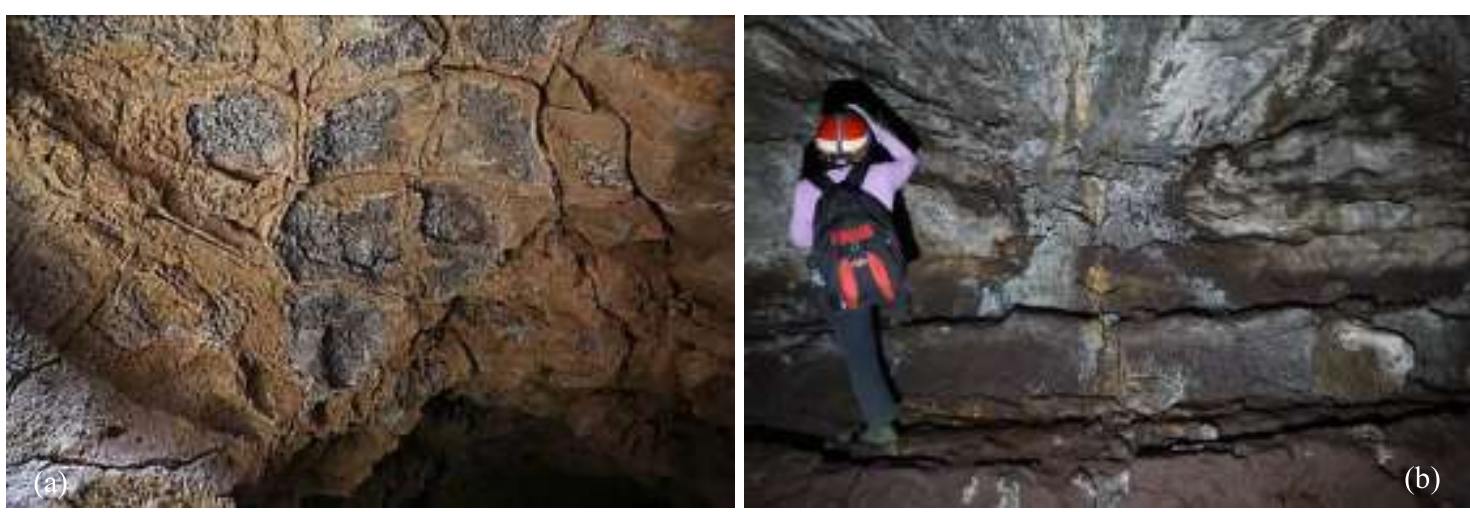

Figure 17. a) Contraction cracks in the $\mathrm{C} 2$ ceiling due to volume reduction. Polygons on the ceiling're about $4-6 \mathrm{~cm}$ long each side; b) Tectonic fractures cut through the formations in $\mathrm{C} 9$ cave

\subsubsection{Pahoehoe and A'a floor}

A cave floor made of pahoehoe lava may have high (melting) temperature and low viscosity (Dave Bunnell, 2014; Larson C.V., 1991). Pahoehoe lava surface in a lava cave is usually flatly smooth, some have ropy-shaped structure. In reality, more A'a lava floor type is found (such as caves $\mathrm{C} 0, \mathrm{C} 1, \mathrm{C} 2, \mathrm{C} 3, \mathrm{C} 4, \mathrm{C} 6$, etc.) as compared to pahoehoe type in cave $\mathrm{C} 7$ (Figure 18a). This phenomenon may be explained by the fact that early formed pahoehoe lava floor was fragmented and mixed with later hot lava flows, then solidified to become A'a lava floor (Figure 18b).
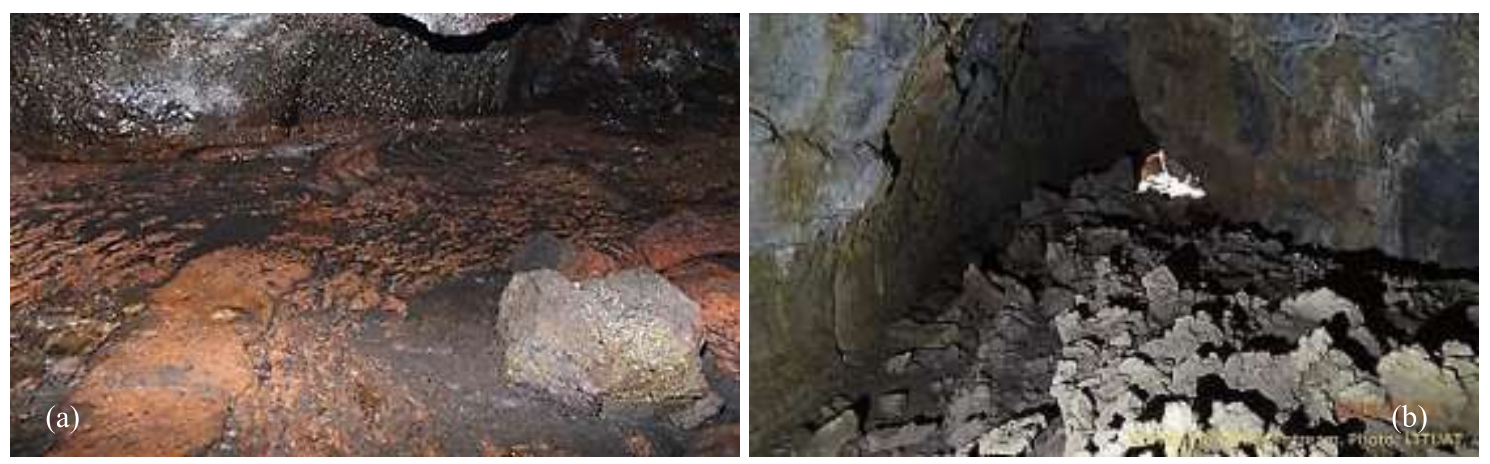

Figure 18. a) Pahoehoe floor in $C 7$ cave (the picture's width is equivalent to the lava flow $4.5 \mathrm{~m}$ wide in the cave);

b) A'a floor in the $3 \mathrm{~m}$ wide-downstream of C2 lava cave 
3.5.12. Typical lavacicles (lava stalactites and lava stalagmites)

Lavacicles (lava stalactites and lava stalagmites) in the lava caves in KVG have two types of origin. Primary lavacicles are widespread that formed during the formation of the lava cave as a result of the filter pressed segregation or segregation emergence (Allred, 1997b, Ogawa T., 1993). They occur in diverse forms, including tubular, drop-shaped, shark-teeth shaped, tube-shaped, sprayshaped, rose-shaped, ribbon-shaped, mushroom-shaped, etc. Primary lavacicles are normally glassy black as their basaltic composition (Figure 19a, b, c) or turn red due to the oxidation phenomenon near the openings of lava tubes (Figure 19d).

Secondary lavacicles are mostly carbonate in composition, formed after the cave formation, and are controlled by external factors. The formation process is mainly similar to that of a stalactite in a limestone cave. In some cases, a secondary lavacicle developed based on a primary lavacicle, serving as a frame. In other cases, secondary lavacicles appear as stone bells, distributing linearly along a ceiling or wall crack, or as stalagmites growing from the floor (Figure 19e).

In Krongno volcanic caves, lavacicles of primary type are predominant to those of the secondary one. Detail study of lavacicles, their origin and formation mechanism may shed light on the cave formation mechanism, hydrodynamic property of the lava flow as well as the following external processes (Figure 20).
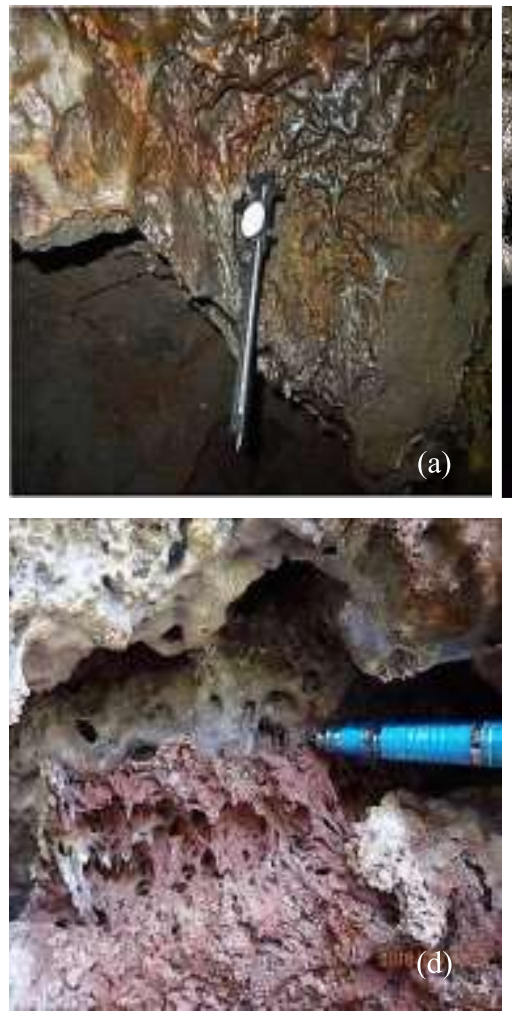
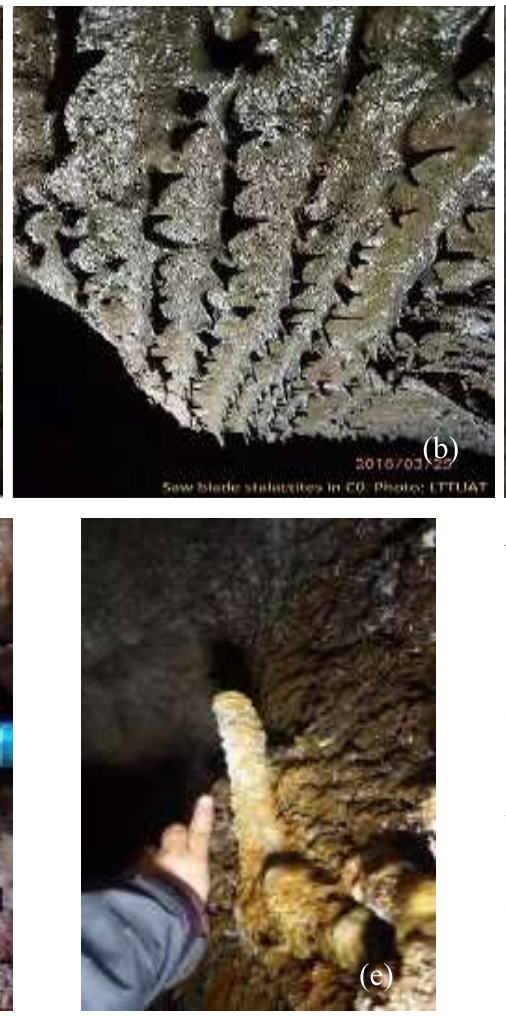

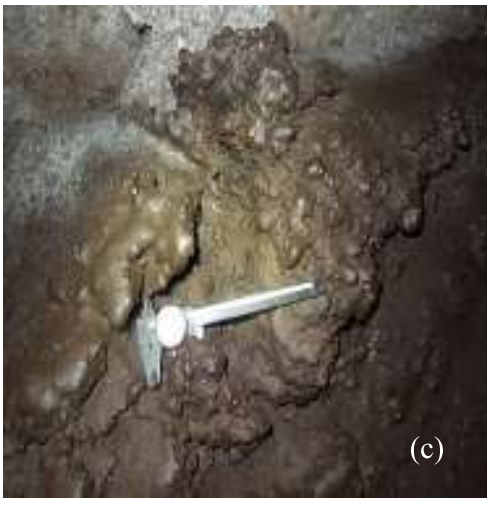

$\leftarrow$ Figure 19. a) Primary stalactites in C3 lava cave (the $295 \mathrm{~mm}$ long caliper as a scale); b) The rows of saw-shape stalactites in $\mathrm{C} 0$ cave. The average interval between different saw-rows: 5-7 $\mathrm{cm}$; the average height of saws: 2-3 cm; c) Primary stalactites in $\mathrm{C} 8$ cave; d) Two different stalactite generations near the C6.1. entrance; e) A big secondary stalagmite in a linga-shape found in P8 cave 
Vietnam Journal of Earth Sciences, 40(4), 299-320

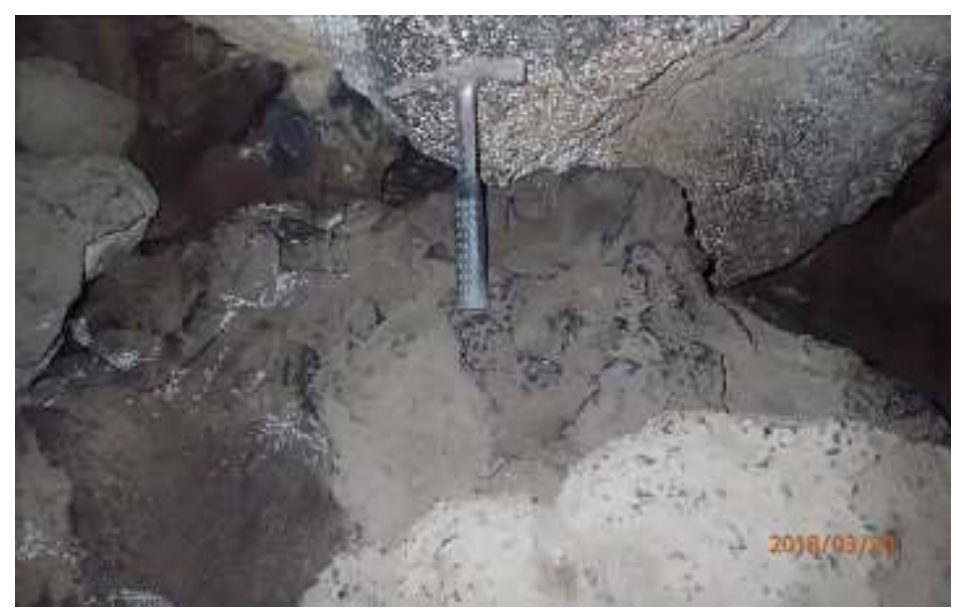

Figure 20. Lava glaze in C6.1 cave

\subsubsection{Lava glaze (Lava enamel)}

Lava glaze (lava enamel) may be formed following a remelting of a ceiling or wall basaltic cover (Figure 21). It is fine-grained and glassy black (Dave Bunnell, 2014; Larson CV., 1991). Unlike weathered basaltic rock that is easily fragmented, the glaze is durable to weathering and its physical property is intact.

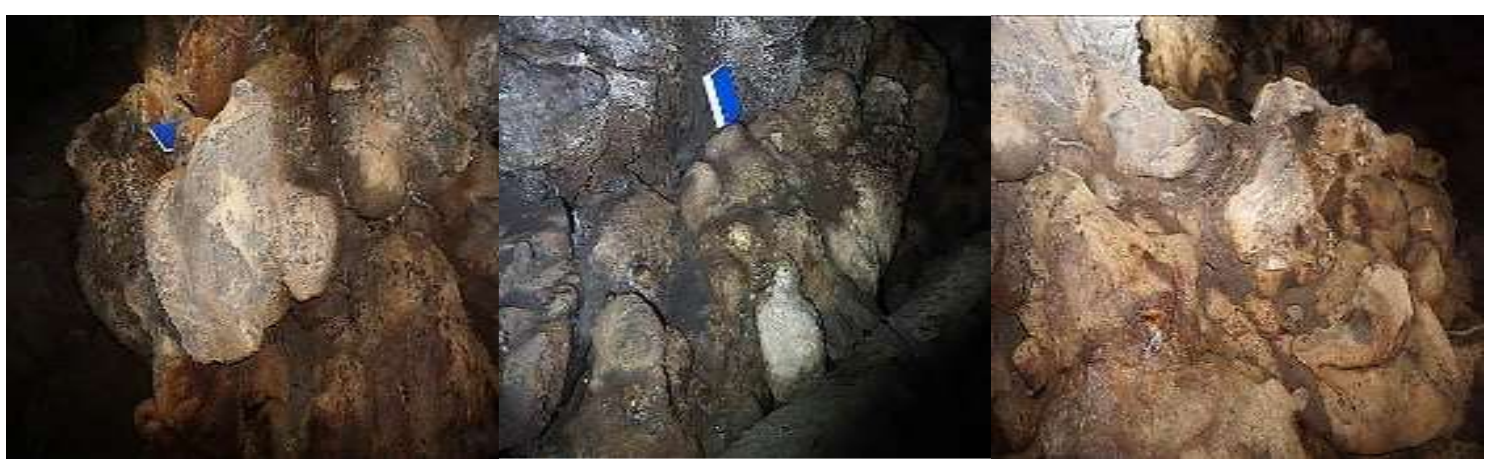

Figure 21. Basaltic pillow lava in the downstream T1 cave

\subsubsection{Pillow lava}

Basaltic pillow lava is formed as hot lava contacts with (lake, river, or sea) water, large enough to suddenly cool the crust of the lava mass (Moreira et al., 2014). Due to the waterflooded in lava tube is rare, thus, pillow lava is rare in the volcanic cave at KVG. However, a few signs of pillow lava structure such as pillow-shaped lava and their glassy crust have been found at the downstream of $\mathrm{T} 1$. The observation suggests that lava tube $\mathrm{T} 1$ may formerly be underwater somewhere in the downstream area when a lava flow reached the site and quenched to form pillow lava structure. Pillow lava structures observed in cave $\mathrm{T} 1$ are typical, which outcrop clearly on the cave floor (Figure 21).

\subsubsection{Lava tree molds}

Lava flows can carry along everything they encounter on the way. Some large trees being transported along a molten lava flow may not instantly be burnt completely. Instead the tree was burnt gradually from outside to inside while the lava cooled and solidified, thus constituting a tree mold in the process (Dave Bunnell, 2014; Gadányi P., 2010). 
The biggest tree mold was discovered in volcanic cave C3 (Figure 22a); the second - in cave $\mathrm{C} 4$ (Figure 22b), some smaller ones have been found in caves $\mathrm{C} 2, \mathrm{C} 4$ and at some large outcrops such as Gia Long, Dray Sap, and Luu Ly waterfalls within the limit of KVG, suggesting that the KVG was a tropical forest in the past.

Aside from the above descriptions, there are a number of interesting structures found in volcanic caves of KVG. Those will be addressed in our next reports.
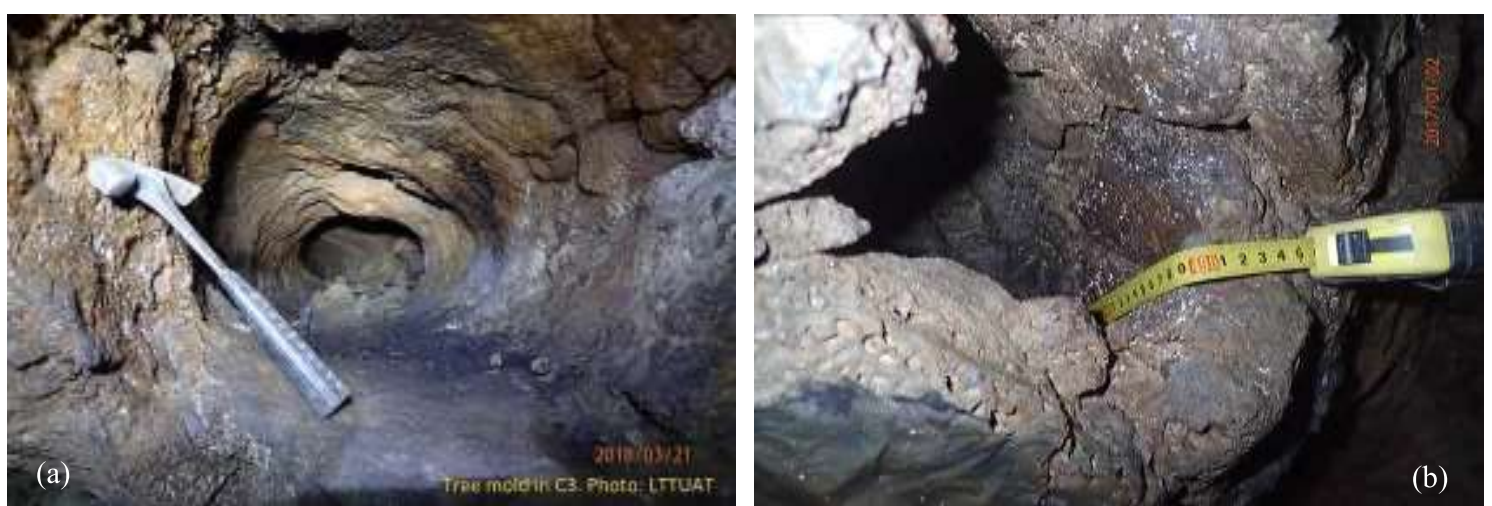

Figure 22. a. The biggest lava tree mold in $\mathrm{C} 3$ cave (a $279 \mathrm{~mm}$ long Estwing hammer's in the pictutre as a scale); b) The second lava tree mold in size of KVG - at least $4.9 \mathrm{~m}$ long in $\mathrm{C} 4$ cave

\section{Discussions}

\subsection{Origin and formation mechanism of lava caves in $K V G$}

In term of classification, all lava caves may be divided into 3 groups: primary, secondary and complex. However, in term of origin, they belong to only 2 origin types: primary/endogenous and secondary.

- Primary/endogenous cave or syngenetic cave (Gadányi P., 2010) is formed in running lava flows, that gradually cool and become solidified.

- Secondary cave or post-genetic cave (Gadányi P., 2010) is formed in a volcanic complex where both explosive eruption and fissural eruption intermediately occur. While explosive eruption may produce volcaniclastic (pyroclastic) layers comprising of tuff, volcanic ash, breccia, etc., fissural eruption produces lava flows. With time weakly cohesive volcaniclastic products can be weathered, eroded and washed away, leaving the empty space, viewed as caves, among solid, massive lava layers.
Besides, the complex cave is constituted by the combination of both internal and external factors. Primarily, small cave tubes can be incorporated in lava flows. The external impact such as weathering, erosion, and washing may convert a small cave into a much larger one.

Field survey and detail study of interior formations of volcanic caves in KVG (such as lava falls, lava shelves, lava levees, lava balls, pahoehoe lava, A'a lava, lavacicles, lava level marks, etc.) show that they were primarily formed directly from lava flows. Formations of the secondary origin, on the other hand, are rare. Therefore, we may come to the conclusion that volcanic caves in KVG belong to the primary/endogenous origin. Some scientists (Honda T. and Tinsley J.C., 2016) described lava caves as "drained lava tubes" and an empty tube after volcano stop eruption, so lava flow drains out of lava tube. The formation of volcanic caves in KVG is one of the unique and interesting geological phenomena. Basaltic lava having low 
viscosity (10 thousand to 100 thousand times higher as compared with water), high temperature(up to $1000-1200^{\circ} \mathrm{C}$ ) (Nelson S.A., 2017), fluid-rich, reached the surface from a great depth of the earth and explosively erupted from Chu B'Luk volcano, spreading onto the surface of La Nga Jurassic terrigenous sedimentary rocks $\left(\mathrm{J}_{2} l n\right)$ to form thick basaltic lava layers. During the eruption process, as outer lava contacted with the air and the surface of Jurassic sedimentary rocks, it gradually cooled and solidified, whereas inner lava was still hot and continued to flow to the downstream. As the volcanic eruption ceased, lava source was gradually exhausted. Lava channels were gradually drained. However, the lava flow continued to advance to some extent under the effect of flow dynamic force, leaving empty lobes behind, on the one hand, pushing released fluid forward to inflate the channel and/or explode to escape (Allred, 1997a; 1997b; Peterson et al., 1994). Volcanic caves in the KVG were possibly formed by the process mentioned above. The fact that there are a large number of volcanic caves, the largest in southeast Asia, may be explained by the effect of erupted volcanic fluid, which was probably increased by the interaction of lava with tropical forest.

\subsection{Episodicity of Krongno volcanic eruptions}

Detail drone image interpretations reveal 4 craters occurred in the Chu B'Luk volcanic area, corresponding to 4 topographic terraces and 4 separate eruption episodes surrounding the Chu B'Luk volcano. Four eruption phases formed different lava flow paths having different route lengths, from the corresponding crater to its destination in the downstream. Preliminary $\mathrm{K} / \mathrm{Ar}$ isotopic age dating on basaltic rocks collected in the Chu B'Luk volcano area were analyzed at $\mathrm{K}-\mathrm{Ar}$ laboratory in Institute for Nuclear Research Hungarian Academy of Sciences (MTA ATOMKI Debrecen, Hungary), its show values ranging from about 689,000 years to about 199,000 years (Table 2).

The formation process of volcanic cave related to Chu B'Luk volcanic eruption was controlled not only by the volcanism, basaltic geochemical composition, physical and thermodynamic properties of lava flows but also by the regional topographic characteristics, vegetation coverage, as well as paleo-environment and paleoclimate conditions.

Table 2. The K/Ar isotopic dating results in KVG (its were analyzed at K-Ar laboratory in Institute for Nuclear Research Hungarian Academy of Sciences (MTA ATOMKI Debrecen, Hungary)

\begin{tabular}{|c|c|c|c|c|c|c|c|c|c|}
\hline $\mathrm{N}^{\mathrm{o}}$ & $\begin{array}{l}\text { No. of } \\
\mathrm{K} / \mathrm{Ar}\end{array}$ & $\begin{array}{l}\text { No. of } \\
\text { sample }\end{array}$ & Location & $(\%) \mathrm{K}$ & Latitude & Longitude & $\begin{array}{c}(\mathrm{ccSTP} / \mathrm{g}) \\
\text { 40Arrad }\end{array}$ & $\begin{array}{r}40(\%) \\
\text { Arrad } \\
\end{array}$ & $\begin{array}{c}\mathrm{K} / \mathrm{Ar} \text { age } \\
(\mathrm{Ma})\end{array}$ \\
\hline 1 & 8790. & KRN 01-1 & Ninh Giang, Buon Choa'h & 1.053 & $12^{\circ} 28^{\prime} 23.3^{\prime \prime}$ & $107^{\circ} 58^{\prime} 54.3^{\prime \prime}$ & $8.1487 \times 10-9$ & $1.8(1)$ & $0.199 \pm 0.02$ \\
\hline 2 & 8791. & $\mathrm{KRN} 05(-20 \mathrm{~m})$ & Buon Choa'h, Buon Choa'h & 0.998 & $12^{\circ} 28^{\prime} 5.8^{\prime \prime}$ & $107^{\circ} 58^{\prime} 38.8^{\prime \prime}$ & $2.5156 \times 10-8$ & 7.3 & $0.648 \pm 0.01$ \\
\hline 3 & 8792. & KRN 14 & SW slope of Chu B'luk Crater & 1.101 & $12^{\circ} 28^{\prime} 25.4^{\prime \prime}$ & $107^{\circ} 56^{\prime} 35.2^{\prime \prime}$ & $1.9739 \times 10-8$ & 3.7 & $0.461 \pm 0.01$ \\
\hline 4 & 8794. & KRN 18-2 & Dray Sap Waterfall & 1.134 & $12^{\circ} 32^{\prime} 13^{\prime \prime}$ & $107^{\circ} 53^{\prime} 23^{\prime \prime}$ & $3.0038 \times 10-8$ & 5.7 & $0.681 \pm 0.01$ \\
\hline 5 & 8845. & KRN-NJ-1 & Nam Dong Crater & 0.911 & $12^{\circ} 38^{\prime} 24^{\prime \prime}$ & $107^{\circ} 49^{\prime} 54^{\prime \prime}$ & $1.9652 \times 10-8$ & 3.6 & $0.401 \pm 0.17$ \\
\hline 6 & 8846. & KRN-C1-3 & Wall of $\mathrm{Cl}$ cave & 1.148 & $12^{\circ} 31^{\prime} 10.9^{\prime \prime}$ & $107^{\circ} 53^{\prime} 34.3^{\prime \prime}$ & $2.5656 \times 10-8$ & 7.4 & $0.668 \pm 0.12$ \\
\hline 7 & 8847. & $\mathrm{KRN}-\mathrm{C} 2-3 \mathrm{M}$ & Wall of $\mathrm{C} 2$ cave & 1.124 & $12^{\circ} 31^{\prime} 10^{\prime \prime}$ & $107^{\circ} 53^{\prime} 35.4^{\prime \prime}$ & $3.0338 \times 10-8$ & 5.6 & $0.671 \pm 0.17$ \\
\hline 8 & 8848. & KRN-C6-1 & Ceiling of C6.1 cave & 0.986 & $12^{\circ} 30^{\prime} 51^{\prime \prime}$ & $107^{\circ} 53^{\prime} 59.8^{\prime \prime}$ & $2.9838 \times 10-8$ & 5.7 & $0.689 \pm 0.16$ \\
\hline
\end{tabular}

\subsection{Paleogeographic environment of the volcanic area}

Tree molds of various sizes are usually found not only in volcanic caves but also in basaltic lava layers throughout KVG. The discovery suggests that Krongno area was then a tropical forest. The branching observed in cave C7 suggests that lava channels blocked streams, constructing natural dykes and forming lakes and swamps that were 
filled with peat and mud such as lake Ea Sno, and those in the Ho Da area. This observation may imply that paleo-topographic surface must have a network of rivers, streams, and paleovalleys. The occurrence of the pillow lava structure in some volcanic caves, although not common, indicates that they were submerged at the time lava reaching the site.

\section{Conclusions}

From the above descriptions we come to the following conclusions:

As of March 2018, 45 volcanic caves have been discovered in $\mathrm{KVG}$, from which 20 caves with a total length of $7721.3 \mathrm{~m}$ were studied and mapped. The formation of volcanic caves in KVG is of endogenous origin. Volcanic caves were constituted in lava flows/channels erupted from Chu B'Luk volcano in the Quaternary stage, Xuan Loc formation $\left(\beta \mathrm{Q}_{1}{ }^{2} x l\right)$.

The distribution and geomorphological characteristics of volcanic caves were dominated by paleogeographic relief, rock composition, physio-chemical and hydrodynamic properties of lava flows.

Although the formation mechanism of volcanic caves is generally similar, each of the volcanic caves of KVG shows their individual distinctions in distribution characteristic, length, shape, branching- flooring and interior formations. These characteristic distinctions constitute the diversity of volcanic caves in KVG.

Lava cave and the interior lava formations with their scientific values become pillar geological heritages of KVG to boost tourism and sustainable development of the Geopark.

Volcanic caves in KVG are endogenously originated with special formation mechanism and are sensitive to natural and human factors as well. Therefore, any human activity and KVG infrastructure construction special attention must be paid to avoid the possible harm to the non-renewable heritage system, which can lead to grave consequences. The use of monorail technology in transport infrastructure construction may be a reasonable method of transport to the volcanic cave area. This method may minimize the negative impact to the heritage during the process of exploiting the heritage value, such as ensuring the integrity of forest ecosystems, reducing $\mathrm{CO}_{2}$ emission, minimizing noise, managing visitors and human waste, while promoting the efficient use of geological tourism of KVG.

\section{Acknowledgments}

We thank UNESCO National Committee of Vietnam, Vulcano-Speleological Society of Japan, We are acknowledged Lien Thanh Construction and Investment JSC, Phu Gia Phat - HCM Investment JSC, Mrs. Hoang Thi Bien (Nico Nico Yasai Co Ltd) for their grateful help and support. Collaboration and support by Vietnamese and Japanese friends and colleagues, and Dak Nong local residents during our study of KVG are highly appreciated.

The paper was conducted under the financial support to the project entitled "Survey and study of geological heritages aim to develop a geological park in the Krongno area, Dak Nong" (2016-2018) funded by Dak Nong province, and "Survey and study of volcanic cave heritages with the aim to construct on-site conservation museums in The Central Highlands, taken lava caves in Krongno, Dak Nong province as an example (2017-2020)"coded TN17/T06 within The Tay Nguyen Program, 2016-2020 period.

\section{References}

Allred K., Allred C., 1997. Development and morphology of Kazumura Cave, Hawaii. Journal of Cave and Karst Studies, 59(2), 67-80.

Allred K., Allred C., 1997. Tubular lava stalactites and other related segregations. Journal of Cave and Karst Studies, 60(3), 131-140.

Barnabás Korbély, 2014. Diverse volcanic features as dominant landscape elements and pillars of geotourism in the Bakony-Balaton Geopark, 
Vietnam Journal of Earth Sciences, 40(4), 299-320

Hungary. Abstract Book Workshop "Geoparks in volcanic areas: sustainable development strategies", October $29^{\text {th }}$ to November $1^{\text {st }}, 2014$. Terceira and Graciosa Islands, Azores Global Geopark, 35-38.

Bird Deanne K., et al., 2014. Southern Iceland: Volcanoes, Tourism and Volcanic Risk Reduction. In Volcanic Tourist Destinations. Springer, Editors: ErfurtCooper, Patricia (Ed.). ISBN: 978-3-642-16190-2, 35-46.

Cooper Malcolm J.M., 2014. Volcanic National Parks in Japan.In Volcanic Tourist Destinations. Springer, Editors: Erfurt-Cooper, Patricia (Ed.). ISBN: 978-3642-16190-2, 231-246.

Dave Bunnell, 2014. The virtual lava cave.Created: August 4, 2000. Last update: December 16, 2014. Reviewed by Kevin \& Carlene Allred. Available at: $<$ http://www.goodearthgraphics.com/virtual_tube/v irtube.html). Date accessed: 02 May 2018.

Gadányi P., 2010. Formation, types and morphology of basalt lava caves. PhD. Thesis. University of Pécs Faculty of Natural Sciences Doctoral School of Earth Sciences, Hungary, 1-19.

Gaki-Papanastassiou, Kalliopi, et al., 2014. Volcano Tourism in Greece: Two Case Studies of Volcanic Islands.In Volcanic Tourist Destinations. Springer, Editors: Erfurt-Cooper, Patricia (Ed.). ISBN: 978-3642-16190-2, 69-87.

Honda T., Tachihara H., 2015. Vietnam Volcanic Cave Survey. e-NEWSLETTER, UIS Commission on Volcanic caves, 69, 11-12.

Honda T., Tinsley J.C., 2016. Classification of lava tubes from Hydrodynamic models for active lava tube, filled lava tube and drained lava tube. $17^{\text {th }}$ International Vulcanospeleology symposium in Hawaii, USA. Sponsored by the Commission on volcanic caves of the International Union of Speleology.

Larson C.V., 1991. Nomenclatures of lava tube features. $6^{\text {th }}$ International Symposium on Vulcanospeleology in Hawaii. Published by the National Speleological Society, 231-248.
Laumanns M., 2013. Important Lava Tube Caves found in Dong Nai Province Southern Vietnam. e-NEWSLETTER, UIS Commission on Volcanic caves, $67,13$.

Machado M., Lima E., 2014. Geotourism and sustainable development partnerships in the Azores Geopark. Abstract Book Workshop "Geoparks in volcanic areas: sustainable development strategies", October $29^{\text {th }}$ to November $1^{\text {st }}$. Terceira and Graciosa Islands, Azores Global Geopark, 45-48.

Moreira Jasmine Cardozo, et al., 2014. Tourism and Volcanism in the Canary Islands, Spain. In Volcanic Tourist Destinations.Springer, Editors: ErfurtCooper, Patricia (Ed.). ISBN: 978-3-642-16190-2, 47-55.

Nelson S.A., 2017. Volcanoes and Volcanic Eruptions. EENS 1110. Physical Geology. Tulane University. New Orleans, USA.

Nguyen Duc Thang (Ed.), 1989. Geology and Mineral Resources of Ben Khe-Dong Nai sheet at scale 1:200,000. General Department of Geology and Minerals of Vietnam. Hanoi. Nunes, João Caros., 2014. The Azores Archipelago: Islands of Geodiversity. In Volcanic Tourist Destinations. Springer, Editors: Erfurt-Cooper, Patricia (Ed.). ISBN: 978-3-642-16190-2, 57-67.

Nunes João Caros, 2014. Azores Geopark volcanoes and volcanic landforms. Valuing the Azorean geodiversity and geossites through the geotourism. Abstract Book Workshop "Geoparks in volcanic areas: sustainable development strategies", October $29^{\text {th }}$ to November $1^{\text {st }}$. Terceira and Graciosa Islands, Azores Global Geopark, 41-43.

Ogawa T., 1993. On lava caves in Japan and vicinity. Proceedings of the Third International Symposium on Vulcanospeleology, 56- 73.

Patricia Erfurt-Cooper, 2014. Volcanic Geo-heritage. Sustainable Tourism Development in Volcanic, 23-25.

Peterson D.W., Holcomb R.T., Tilling R.I., Christiansen R.L., 1994. Development of lava tubes in the light of observations at Mauna Ulu, Kilauea Volcano, Hawaii. Bulletin of Volcanology, 56, 343-360. 